\title{
The Road To Dumbiedykes
}

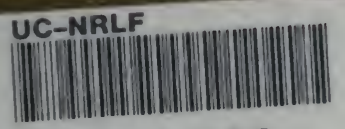

\$B $158 \quad 425$ 


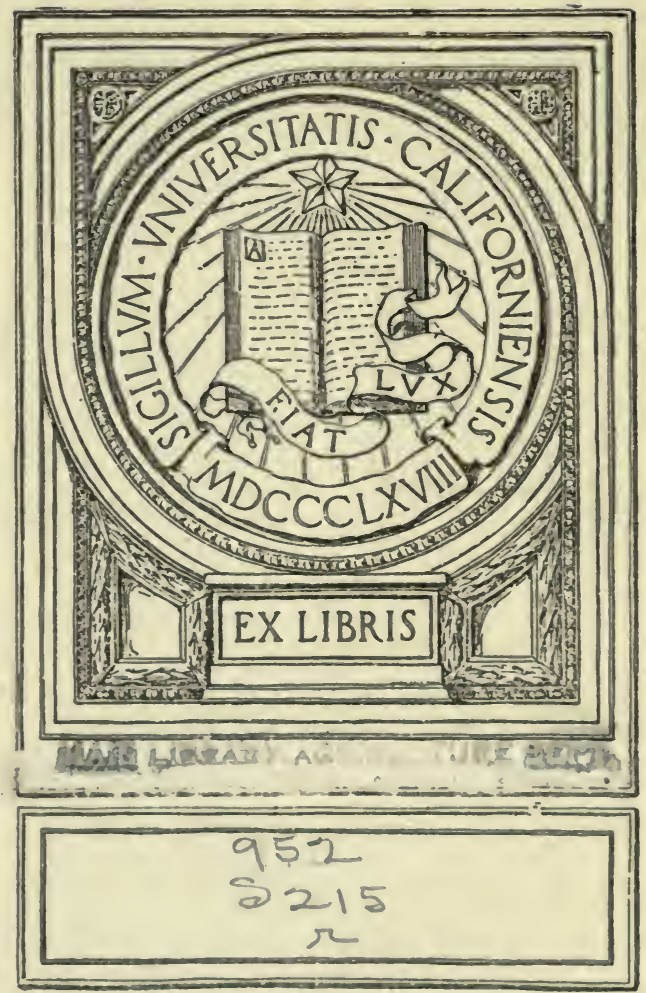



The Road To Dumbiedykes 
Digitized by the Internet Archive in 2007 with funding from Microsoft Corporation 



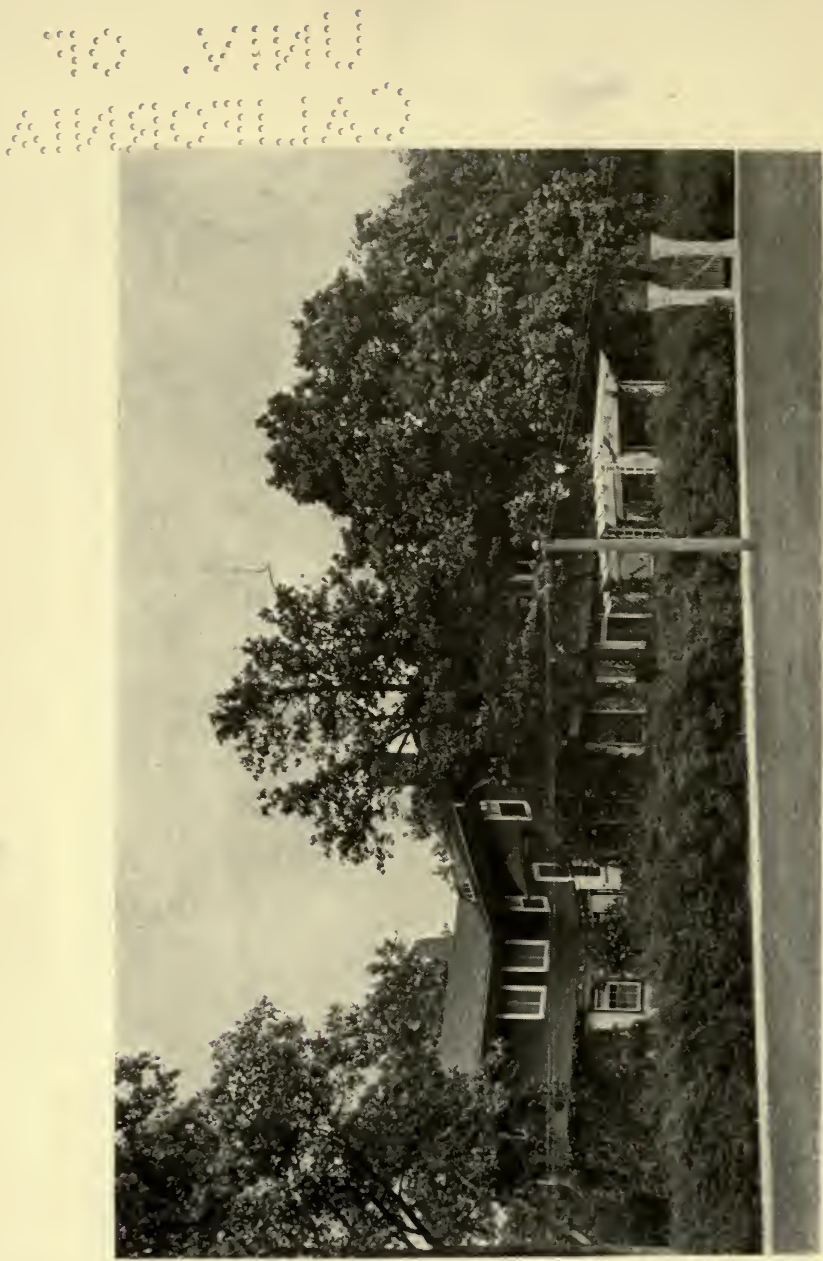

ปs 


\section{The Road \\ To Dumbiedykes}

Some Rambling Thoughts
of One Who Found It

By

Alvin Howard Sanders

Editor "The Breeder's Gazette"

Author of "The Story of The Herefords," "At the

Sign of the Stock Yard Inn," etc.

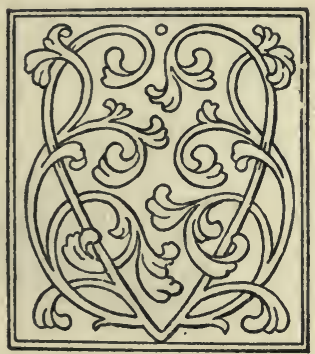

Chicago

Sanders Publishing Company

1920 
Copyright, 1916

Sanders Publishing Company

All Rights Reserved

(4), 57

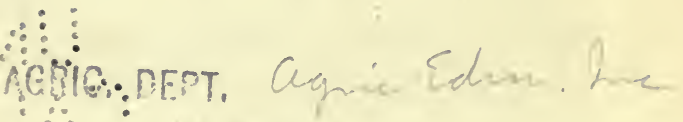

un e

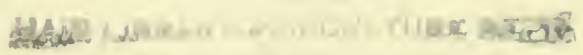


To "Billy"

465343 
A PIECE of land not very large, Wherein there shall a garden be, $A$ clear spring flowing ceaselessly, And where to crown the whole there should $A$ patch be found of growing wood.

Horace. 


\section{Contents}

CRAPTER

I. A Boy ANd A Dog . . . 9

II. A Brick House with a Past 2 I

III. "The Heart of MidloTHIAN" • . . . . . 29

IV. The Bluegrass Claims its

OWN . . . . . . . 39

V. Midsummer Night Alarms 55

VI. The Coming of the Dawn . 65

VII. Dumb Walls . . . . 8I

VIII. The Garden Gate . . . 89

IX. The Tragedy of the Flying SQuirrels • • • • 99

X. Toilers and Idlers of the Shining Hours . . . . II3

XI. The Rain upon the Roof . 123

XII. Fireside Fancies . • . 129

XIII. The Beginnings of To-Mor-

ROW • • • • • • . 139

XIV. Back to the Bright Lights I45 



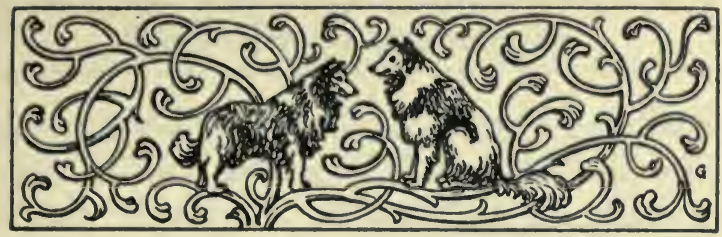

\section{The Road to Dumbiedykes}

\section{CHAPTER I \\ $A$ Boy and a Dog}

The keeping of Collies, Fox Terriers and in fact most other' kinds of dogs in cities is a crime. I speak of course of real dogs, not those poor degenerates you may see in my lady's limousine or lap. These may be interesting to the student of animal breeding as illustrations of how men can emasculate the brute creation through the application of well understood principles of selection, blood concentration and outcrossing, but the results are not to my mind particularly edifying.

It is interesting doubtless to know that animals that are all body with no legs can be produced. It is inter- 
esting, I suppose, to some to know that a dog that is all legs and snout, possessing no middle, can be bred. It is interesting perhaps to see a breed that has no nose nor brain, but what is found to admire in such freaks is a query put by many people possessing sound minds in sound bodies. However, "de gustibus non est disputandum." I have no quarrel with those who like canine canaries; but as for myself give me the virile, normal animal that bears some resemblance to the primal product of the wilds.

I love dogs. That's why I don't own one. There is no place for them in town, and I can spend only a few months each year in the country. Moreover, you become too attached to a good intelligent pup. He grows into your affections in real human fashion. So much so that when you lose him under the wheels of a motor or from natural causes you find that too strong a hold has been laid upon 


\section{$A$ Boy and a Dog}

your sympathies. That's why you hear of so many "dog cases" in the country courts. That's what moved Senator Vest to say, upon a certain memorable occasion:

Gentlemen of the jury: The best friend a man has in this world may turn against him and become his enemy. His son or daughter that he has reared with loving care may prove ungrateful. The people who are prone to fall on their knees to do us honor when success is with us may be the first to throw the stone of malice when failure settles its cloud upon our heads. The one absolutely unselfish friend that a man can have in this selfish world, the one that never deserts him, the one that never proves ungrateful or treacherous, is his dog.

Gentlemen of the jury, a man's dog stands by him in prosperity and in poverty, in health and in sickness. He will sleep on the cold ground, where the wintry winds blow and the snow drives fierce, if only he may be near his master's side. He will kiss the hand that has no food to offer; he will lick the wounds and sores that come in encounter with the roughness of the world. He guards the sleep of his pauper master as if he were a prince. When all other friends desert he remains. When 


\section{The Road to Dumbiedykes}

riches take wings and reputation falls to pieces, he is as constant in his love as the sun in its journey through the heavens. If fortune drives the master forth an outcast in the world, friendless and homeless, the faithful dog asks no higher privilege than that of accompanying to guard against danger, to fight against his enemies, and when the last scene of all comes, and death takes the master in his embrace and his body is laid away in the cold ground, no matter if all other friends pursue their way, there by his grave-side will the noble dog be found, his head between his paws, his eyes sad but open in alert watchfulness, faithful and true even in death.

So what's the use? But, getting back to our original proposition, I say that the confining of a Collie to the dreary monotony of back yards and city pavements is putting as great an outrage upon Nature as is the caging of a scarlet tanager. He may live for a while, but his life will be a hollow mockery. The enforced repression of the wanderlust that inheres in the active brain of every true Fox Terrier - the bravest creature of his size in 


\section{$A$ Boy and a Dog}

the animal world - is as cruel a proceeding as the slow murder of a skylark behind steel wires. Life in each case, while it lasts, is indeed a ghastly failure.

The lot of a country-bred man or woman trying to be happy between two brick walls in a city flat is bad enough. But commonly they could escape from an imprisonment, often self-imposed, if they only would. Frequently they hold within their own grasp the key that would unlock the bars. Not always, to be sure; and when fate ordains that they shall never more regain touch with the out-of-doors, then indeed is the case pathetic beyond any parallel to be drawn from the brute creation.

I once knew a boy who at sixteen years of age was captured and transported from gardens and apple orchards to a hall bedroom in a boarding house that once stood one city block from where the Blackstone now rears its 


\section{The Road to Dumbiedykes}

graceful front. He did not even have the melancholy satisfaction of occupying it alone. In order that a little more might be saved out of a \$10 weekly wage, he divided both room and rent with a fellow-boarder who was in a somewhat similar predicament. This f. b., by the way, is now a man whose name is often seen and heard these days in connection with important local and national affairs, and the old partnership on Michigan Avenue is not infrequently recalled when these men meet.

The boy had left behind him in the country, among other things, a pony and a dog. Naturally there was no place for such impedimenta in that upper hallway. Now, parting with a pony that you have petted and fed for years is no joking matter. Together this particular pair of which I speak had explored every roadway for miles around. Together they had galloped up and down the pastures 


\section{$A$ Boy and a Dog}

where the cattle grazed. Together they had waded in the water where the creek was forded. They understood each other perfectly, and you don't know just what fate awaits a companion like that when you deliberately take your way to the city streets and leave him out there to the tender mercies of strangers. Maybe they will be kind to him. I don't see how they could be otherwise if they really know him. But maybe he will fall into hands that will not appreciate him. Maybe he will be abused. So saying goodbye to the pony of your youth is one of the first real sorrows of your life. And yet those words of George G. Vest cannot fairly be applied to an equine chum, however fond you may be of each other. Your pony will not be long in adapting himself to the individuality of a new master. A sufficiency of oats and hay at opportune moments will go a long way towards reconciling your dear old pony 
to any loss he may fancy he has suffered. For even as the prophet saith: "The ox knoweth his owner and the ass his master's crib."

But with your dog it's different. You don't really know what grief is until you are a boy ruthlessly dragged away for good and all from a Collie you have owned. Collies are peculiar dogs - shy and suspicious of strangers, but tied with hoops of steel to one who has their confidence. Unlike your roving terriers, all boys do not look alike to a Collie. He takes not up with the first fellow he may chance to meet, no matter how civil be the greeting. He does not make friends readily. $\mathrm{He}$ is chary of his affections. He is not a good mixer. With him the social instinct is not highly developed. He only knows his own and his master's own, and in respect to that stands ever on the defense, and in this sacred service he will do or die. 


\section{$A$ Boy and $a \cdot D o g$}

But there was no place for him nor any other dog in that bedroom there three hundred miles away. And for the first time the boy now began to realize that when he migrated to the great city by the lake the curtain was falling forever upon an act complete. Probably this Collie would have been a better work dog, so far as helping in the handling of the live stock was concerned, had the boy not played with him so much. This doubtless detracted from his selling value for practical farm purposes. Many dogs were infinitely his superior in working flocks and herds, but whatever he lacked in point of skill at the heels of sheep or cattle he more than made up, from the boy's standpoint, by the splendid intimacy of his constant companionship and the zest with which he entered into various games jointly devised. And one sad day the boy and dog had their final romp. The boy knew it was the end, and his heart 
was in his throat, but the dog did not; so the weight of the impending blow was only felt by one.

The boy unpacked his little trunk a few days later to begin serving an indeterminate sentence at office work. One morning on the city street he passed a Collie on a leash. The day was warm and the dog was muzzled. The look of hopeless despair the country boy detected in that Collie's eyes has not yet been forgotten, and he vowed then and there that he, for one, would never be a party to any scheme looking towards the transfer of any living creature of the open to prison pens within a city's walls. And he has kept the faith.

What became of his own abandoned dog he never knew, nor desired to know. He did not seek bad news where he knew there could be none that was good, but he always believed that his Collie must have died sooner or later of something akin to a broken heart. 


\section{$A$ Boy and a Dog}

Years passed. Engrossed in work and saddled with ever-increasing responsibilities, the man had little time to think of the world beyond the gates; but he often dreamed of a certain shaggy sorrel pony and a Collie racing madly out and back again in a game once played where skies were blue, and the turf was green, and the grass was soft and thick and cool beneath bare feet.

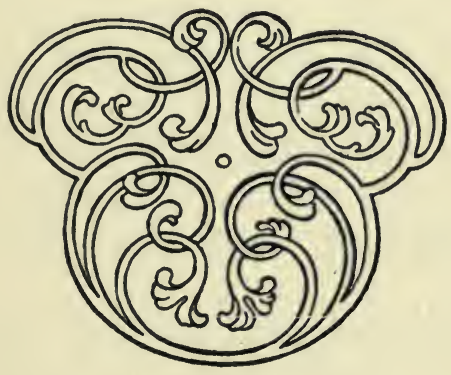





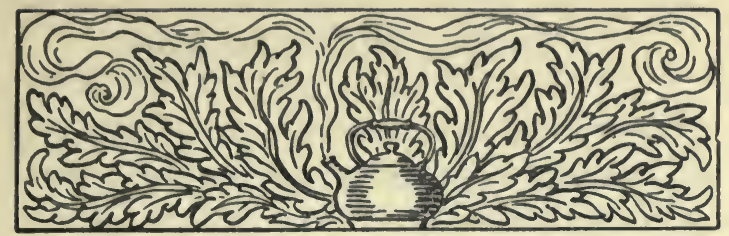

CHAPTER II

A Brick House with a Past

Something like twenty-five miles from the great city's congested centre, if your course has been rightly laid, you will come upon what appears to be the entrance to a country estate of some importance. There are two brick piers with gates of iron which commonly stand ajar. If you enter and are of an observing turn of mind, you may note in passing that the designer of these gates has used as a decoration in working out the detail of his conception the figure of a heart.

In that field on your left there will be corn or oats or meadow - depending upon the stage of crop rotation registered for that particular season - 


\section{The Road to Dumbiedykes}

and a good, rich, level forty you will find it too, though it wants tile. That peculiar "humpy" condition of the turf in the pasture on your right which is not a part of the property of which we speak - reflects even more clearly a demand for drainage.

The driveway will lead you along a row of stately maples at the end of which the land rises, and if your eyes are keen, as you round a sharp curve up a slight elevation, you may catch a glimpse of what was once an old farmhouse, all but hidden in the trees, where it is aging peacefully in deep seclusion.

It is a house with a history. Of that make no doubt. The only trouble is we don't know the history. However, that makes no real difference. What we do know, and what must necessarily have been the situation in the years long gone, will enable us to contrast without special difficulty its past and present. A great change 
has come over the scene since one day, now more than twenty years ago, a party of city business men pulled up at the old house to look over the farm, of which it was the heart, with a view towards purchasing.

It seems an ordained part of old Dame Nature's general scheme to obliterate as soon as possible all traces of departed activities. Streets and rails, no matter what their importance as commercial arteries, once abandoned are soon claimed by grasses and other plants appointed for such tasks. The apparently indestructible yields at last to the inexorable levers and fulcrums with which old Father Time is so generously provided. And so we find that year by year the vines and trees and shrubbery are gripping tighter and tighter in their sheltering embrace these old brick walls. It is, in truth, now so well protected from the vulgar public gaze that unless you know just where it stands you will 
miss it entirely as you pass. Indeed, were it not for the fact that it is the subject of an annual overhauling, and its interior kept in readiness for guests who may not find accommodation elsewhere upon the property - of which it is now a more or less unnecessary part - the porches, windows, roof and floors would in due course fall a prey to the operation of the natural laws that work unceasingly in the physical world.

With my own hands, some years ago, I set some of the roots that now supply leafy cover to those walls, and for this act I am sure that the spirit that dwells within is duly grateful. I speak thus because it was long since vacated by once happy, frugal and industrious tenants, and possesses now no regular occupants. I am always sensible of some unseen presence in such cases. Not that I know or care anything particularly about occult theories, for they do not specially 


\section{A Brick House with a Past}

interest me; but it pleases my fancy, now and then, to set up for my own mental stimulation some presiding genius as watching ever over old houses that have once been the stage of human weal or woe.

You will listen now in vain for the voices of the children playing in the garden. They have disappeared. That is all we know about them. The kettle sings no more its song of cheer and comfort in what was once the kitchen. And, by the way, does anyone know of any note within the whole range of domestic economy so suggestive of real creature comfort as the busy babble of the vapor as it finds its sputtering vent through dancing lid or steaming spout? We do not hear it often enough in these latter days for the best interest. of the family circle. Homes have been broken up, I have no doubt, that might have been held together had husband and wife been more familiar with the story old, 


\section{The Road to Dumbiedykes}

yet ever new, told by the cosy kettle on the evening fire.

For some time after this farm was taken over by its new proprietors, meals were occasionally served to those whose business took them there in the old dining-room as in the time of the original builder and subsequent owners. And so it chanced that one day I sat a-listening to the kettle singing to itself as I waited to be served. Straightaway I felt myself transported back across the flood of years to a big, old-fashioned kitchen in a farm home far away, where a dear oldfashioned mother held her own delightful sway; and the memories that came trooping were of pies and cakes and things such as have not since been made at all for epicures or kings. But food is no longer to be had in this old brick house. Its commissary department is out of commission, probably forever.

The electric bulb has of course supplanted the candles and the lamps, 


\section{A Brick House with a Past}

and the lanterns that once lighted the farmer and his men to the early morning work gleam no more in the darkness that precedes the tardy winter dawn. Gone also is the big frame barn with its warm stone basement where the cattle were housed from the cold and storms. Gone are the stalls where the farm teams stood to their corn and oats, and rested from hard labor at the plough. Gone the great floor where the implements of a thrifty husbandry were safely sheltered. Gone the great loft where the hay was snugly stowed, and ambitious hens once made their nests.

Where all this once was you will now see a handsome terrace and a broad flight of steps banked high with flowers and shrubbery. What was a typical barnyard is now a lawn, with a double line of maples down a graveled walk; and, chief change of all, in the very centre of an orchard that was doomed a great Colonial mansion 


\section{The Road to Dumbiedykes}

stands. The apple is indeed a sturdy tree, even in our icy northern clime, if given chance; and so, out in front, you still will find a few brave stragglers of a fruitful race that refuse persistently to abdicate their place; and with each recurring springtime they spread their fragrance far and wide, and shower pink petals on the turf.

A transformation absolute, in short, has overtaken both homestead and outlying fields, and to the whole a name that is truly freighted deep with history and romance has been assigned.

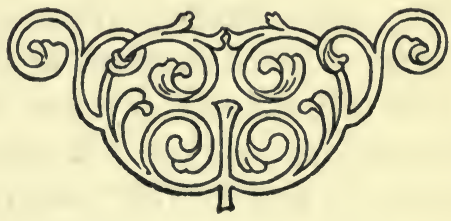




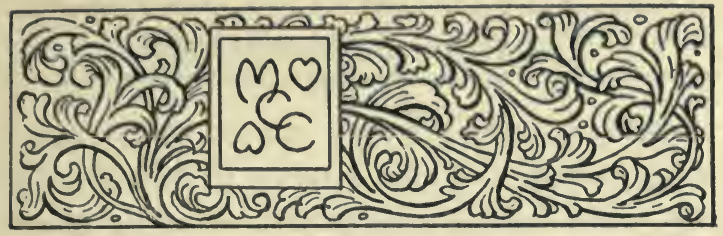

\section{CHAPTER III \\ "The Heart of Midlothian" .}

The first money I ever invested in books of a permanent character went for the purchase of a standard Edinburgh edition of the Waverley novels, embellished with excellently executed steel engraved plates, reproductions of thoroughly artistic originals. I bought them at a time when perhaps the price might better have been invested in something of greater practical utility. Nevertheless I coveted this particular set of books because I loved Scott above all else in literature, and I insist emphatically that I love him still. There they all are now, filling a section in my shelves dearer to me than any other in the library. Not one volume is missing from its accus- 


\section{The Road to Dumbiedykes}

tomed place. True, they are somewhat worn. They surely need rebinding, but I like them best just as they are. I am perfectly well aware that in setting down these facts $\mathrm{I}$ am in the eyes of the younger generation writing myself into a day that has long since passed. Nobody buys Scott nowadays, they tell me. But when I contemplate contemporary fiction I am quite content to be so catalogued, for Ivanhoe and Quentin Durward, Amy Robsart and Jeanie Deans, Richardof-the-Lion-Heart and the Sultan Saladin, Meg Merillies and Lorna of the Fitful Head, Prince Charlie and Rob Roy, and all the rest of that incomparable company are as near and dear to me still, after the lapse of many years, as when the world to me was young.

Many things have happened since that day of the long ago when I exchanged my hard-earned cash for this precious set of Scott. Books, pictures, souvenirs and gifts, mainly valuable 
"The Heart of Midlothian"

because of their associations - those belongings that make life worth living - have since accumulated; but I cannot honestly confess that I prize at the present time any of my possessions higher than the still fascinating volumes that portray so vividly those beloved heroes and heroines of old romance.

He who crosses auld Berwick "brig" and rounds the hills of Lammermoor as he comes upon East Lothian, and knows naught of Walter Scott, is indeed quite altogether unprepared for understanding and appreciating either the North country or its people. Of course if you have the golf bug well developed you can do with a knowledge of "Tam" Morris and St. Andrews. I am fond of the ancient and honorable Scottish game myself, and once permitted the lure of the celebrated seaside links to draw me away from certain studies in other lines of Scottish activity long enough to play nine holes on a 


\section{The Road to Dumbiedykes}

windy day amidst those sand-dunes on the German Ocean. But nine such holes were quite enough; in fact, somewhat more than sufficient. "Jack" Forrest will freely testify to that. I will only remark in passing from an unpleasant subject that there is one particularly unnecessary natural hazard there for which I harbor no affection whatsoever. I decline to publish my card, for the simple reason that I do not court the jeers and ribaldry of unsympathetic souls. In fact, I must concede at the outset that while I have some acquaintance with the methods underlying the grand farming of the Lothians, and of the principles governing the production of "prime Scots" for the Smithfield market, the ways of Scotchmen who can drive a golf ball 250 yards, straight down a fiercely-bunkered course, are past my finding out.

But did you ever view the rising or the setting of the sun from Salisbury 
Crags? If you know Scott's Scotland, and have ever been in the ancient capital of the North, you may have taken Sir Walter's favorite walk at the close of day. And if it chanced to be mid-June you would not have had so very long to wait for the glories of the dawn itself, so short are the hours of darkness at that season of the year in the higher latitudes.

What scenes of pomp and pageantry, what tragedies, what triumphs, have not those heights looked down upon! The joys and sorrows of a people during centuries of turbulence struggling onward, yet ever upward, toward the goal to which they have finally attained. There is the line of the old High Street, every foot of it historic, from the great castle on the rock to Holyrood. In the middle of the old Grassmarket a tablet imbedded in the pavement still carries the figure of a heart - the same heart we saw wrought into the iron fabric of the 
gates as we entered the roadway a little while ago leading up to the old brick house. And if you have read to any profit the enchanting tales of the last great Scottish minstrel, you will not require a guide to interpret the import of the strange inscription "The Heart of Midlothian"- that has challenged the attention of tourists for several generations past. You are standing upon the site of the old Tolbooth prison, long since demolished, but given immortality in the realm of letters by the sage of Abbotsford. Here the wayward Effie Deans awaited execution, while poor Jeanie made the long journey afoot to London to beg for her erring sister a pardon from the crown. The world has almost canonized as a saint this heroine, whose actual prototype was brave, truth-loving Helen Walker of Dundee.

Mid-Lothian! The open country round about "Edina, Scotia's darling 
seat,"* the Athens of the Anglo-Saxon world! There stands the queenly city, now, as ever, the rock of Scotland's hopes, her graceful towers and hoary battlements, her halls of learning and her classic monuments, bathed in the mingled sunshine and the mists that lure the purple heather from the distant Pentland hills! "None know her but to love her." May she endure forever!

Here in America a new heart in a new Midlothian has now been set. It is also a form of prison, in its way one that brings a mild form of grief to certain unfortunates trapped within its walls. But this, our heart, is not a gloomy pile of cold gray stones set up to mark a district's geographic centre. It lies imbedded in soft earth and verdure in the midst of "green

*The Lothians comprise a division of country in Scotland, on the south border on the Firth of Forth, of great extent anciently, but in modern times restricted to the counties of Haddington or East Lothian, Edinburgh or Mid-Lothian, and Linlithgow or West Lothian. When the designation Edinburghshire is used, the words "or Mid-Lothian" are added often, Mid-Lothian used alone not requiring any auxiliary addition. There is a movement on foot to adopt the terms East Lothian for Haddingtonshire, and West Lothian for Linlithgowshire, exclusively, so as to establish harmony of designation. 


\section{The Road to Dumbiedykes}

fields and running brooks," and the only tragedies likely to be enacted in it are such as may attach to temporary discomfitures in the game of golf. It is, in brief, just a simple heart-shaped hazard nicely calculated to punish a "topped" tee shot on the fourth hole of a great playground for tired city folk that was once a beautiful farm presided over by an old brick house.

Here have hundreds walked their way into health and happiness, and into all the joys that go with solid friendships and congenial companionships as they have tramped these alluring links. And here, too, the name of the old "heart" of unhappy memory has become invested with a fairer fame and atmosphere; let us say, with some of the humanizing elements that flow from the exercise of the simple arts of love and service through the employment of which iron bars in Scotland were once thrown back at the gentle touch of Jeanie Deans. 
And so it comes to pass that we have here to record the fact that the gates whereby we reach this new Midlothian swing freely ever to release from bondage the weary wearers of a city's chains. Here they receive indeed the benediction of blue skies, God's sunlight and the open country. It is of certain phases of this blessed liberty amongst the clover blossoms that I, a hardened galley slave, would speak.

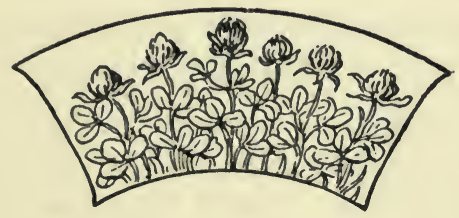





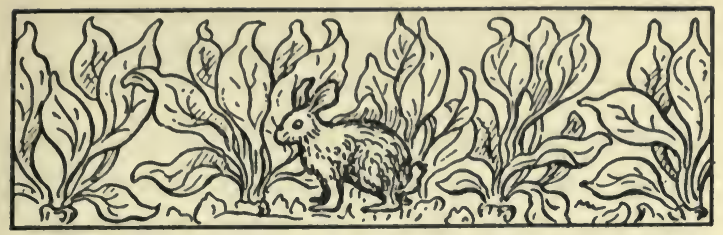

CHAPTER IV

The Bluegrass Claims Its Own

The broad porch of the big manor house builded by the buyers of the Brick House farm, with its great white fluted pillars and "gallery," has a southerly exposure. The view is of purely pastoral simplicity, calculated to soothe and rest tired nerves and eyes, rather than impart any special mental thrills.

A gentle declivity leads down to where a sinuous brook meanders aimlessly through the middle foreground, losing itself finally in a belt of timber on the left, where the flood waters are impounded by a dam. The backwater from this has formed a small lagoon which serves a triple purpose. First of all, it gives golfers a good water hazard to play into or over. Secondly, 


\section{The Road to Dumbiedykes}

down in the deep cover of the wood near the concrete wall that gives permanency to the basin, the small boys, who have to be amused some way when not engaged as caddies on the links, find here entertainment unlimited in fishing with pin-hooks for elusive crabs or bull-heads. To be sure the boys are not supposed to cross a dead-line that has been set up for their restraint, but what normally constituted boy, five miles away from his home in town, loitering about within a stone's throw of a typical oldfashioned swimming hole buried deeply in the shadow of the oaks, could resist a temptation to break a mere caddiemaster's ground rule? And so you will find them there frequently, with a scout commonly watching for the stealthy approach of some one in authority bent on spoiling all their fun. My own path takes me always by this woodland pool, but I never could find it in my heart to drive these very human little 


\section{The Bluegrass Claims Its Own}

chaps away from the mysteries that cluster round that spot.

In the earlier days real muskrats and woodchucks were to be seen at rare intervals working around that dam. They are gone now, but what boy who had ever seen them there could ever forget it or ever dismiss the idea wholly from his mind that they are probably in hiding somewhere still, and that by waiting and watching patiently enough the little furry creatures will sooner or later be seen again in their former haunts? The truth is I haven't the heart to drive those boys away from this fascinating nook when I see them enjoying to the utmost its forbidden precincts. On the contrary, I am often sorely tempted to stop and join them in their explorations or meditations. The noisy bluejays are busy in the branches overhead, tiny wavelets are breaking against the face of the retaining wall, unknown forms of life lurk underneath the surface, and a rabbit hurries by. 
Through the treetops a glimpse of an azure sky is caught. Here indeed is the true heart of Midlothian to be found, and at this shrine I often stop alone and worship.

The third purpose served by our little lakelet is strictly utilitarian. Some day late in the autumn the big valve in the dam is opened. The water nearly all escapes and soon is on its way to the Little Calumet, and thence into the bosom of the big lake itself. The bed of the lagoon is cleaned, the outlet closed, and pure water pumped until the reservoir is again bank full. It is then left there, deserted by all its fair weather devotees, to await the coming of the power that shall lock it tightly in a solid sheet of ice, which later on is duly harvested.

Returning to the wide veranda and resuming our survey of the general landscape, beyond the brook an undulating sea of verdure leads the eye away to where a hedgerow marks the 
The Bluegrass Claims Its Own

southern boundary of the property. Beyond this - the line of a public highway - you catch glimpses of corn and oat fields, distant woodlands, and little farmsteads nestling among the trees. Westward a well equipped and privately conducted scientific agricultural experiment station, operated by one of our enthusiastic back-to-thelanders, is revealed. Its great water tower and the big, hospitable house that crowns an elevation in the middle foreground unite to make Maple Farm a landmark dominating the entire landscape in that direction. Guernseys, Chester Whites, fancy poultry, silos, alfalfa fields and a hundred other objects of interest to farm folk may here be found. Back of this a partlywooded, broken country rolls away towards a remote range of hills, behind which the setting sun goes down into the little valley of the Des Plaines River. Originally covered entirely with a forest growth, clearings here 
and there have introduced the bluegrass in those hills, and red barns, modest homesteads, dairy cows and duck ponds greet the eye of such occasional wanderers as find their way into this delectable region, which is really picturesque and as yet more or less primitive. I have had day dreams of Horatian happiness there to be found sometime in real retirement on some sequestered Sabine farm.

There was a time when what is now a wide expanse of grass was given over to the plough, but as a matter of fact the soil was never specially adapted to successful cropping. The wooded knolls that shut away our outlook towards the east really constitute the first rise of land you meet in traveling westerly from the sandy shores of the lake some ten miles distant; and the stiff rebellious clays of which these first ground-swells are mainly composed give ample evidence of having once been the bed of a great bay ex- 
The Bluegrass Claims Its Own

tending up to the higher lands farther west that form a natural barrier at this point betwixt the little river of the plains and the great body of blue water rolling restlessly beyond the Calumet. Notwithstanding the refractory character of the soil upon these gentle slopes, the Brick House farm was made for many years, through the ameliorating influences of a livestock husbandry, to produce fine yields of oats and occasional good crops of corn. But such lands primarily belong to bluegrass, and as this fitted in exactly with the plans of the new proprietors, it was not long after they took possession that mowers and rakes replaced plows, harrows, cultivators and harvesters as the only implements in use.

The major portion of the property spread out before the big, new house was set aside, by those who were planning this co-operative country home, for conversion from waving grain fields into a modern golf links, and needless 


\section{The Road to Dumbiedykes}

to say, to those who know the nature and habit of the bluegrass, it did not stand long upon the order of its coming. Aided and abetted during the drouthy summer months by its old friend and ever-faithful ally in such work, white clover, so dear to our good friends the busy honey bees, the occupation of the land which the cereals had so recently surrendered was quickly and successfully accomplished. And presently there was naught but beautiful green turf as far as the eye could reach.

The bluegrass loves best the open sun. Still it is quick to take advantage of any opening afforded in our western woodlands, and if you are specially interested in seeing it at its best - or worst, just according as you are judging it from the standpoint of an agronomist or that of a golfer - and chance to be within Midlothian's gates, come with me to the edge of the grove just under the brow of the hill in front of the third teeing ground, almost any 
time from early June to late November, and I will show you a matted mass, as luxuriant a sod as central Kentucky itself may boast. And speaking of this, for the benefit of all who love the sight and the touch of a bluegrass sward and yet know not the existence of this literary gem, let us here interpolate a classic:

Next in importance to the divine profusion of water, light and air, those three physical facts which render existence possible, may be reckoned the universal beneficence of grass. Lying in the sunshine among the buttercups and dandelions of May, scarcely higher in intelligence than those minute tenants of that mimic wilderness, our earliest recollections are of grass; and when the fitful fever is ended, and the foolish wrangle of the market and forum is closed, grass heals over the scar which our descent into the bosom of the earth has made, and the carpet of the infant becomes the blanket of the dead.

Grass is the forgiveness of Nature - her constant benediction. Fields trampled with battle, saturated with blood, torn with the ruts of cannon, grow green again with grass, and carnage is forgotten. Streets abandoned 


\section{The Road to Dumbiedykes}

by traffic become grass-grown, like rural lanes, and are obliterated. Forests decay, harvests perish, flowers vanish, but grass is immortal. Beleagured by the sullen hosts of winter, it withdraws into the impregnable fortress of its subterranean vitality and emerges upon the solicitation of spring.

Sown by the winds, by wandering birds, propagated by the subtle horticulture of the elements which are its ministers and servants, it softens the rude outlines of the world. It invades the solitude of deserts, climbs the inaccessible slopes and pinnacles of mountains, and modifies the history, character and destiny of nations. Unobtrusive and patient, it has immortal vigor and aggression. Banished from the thoroughfare and fields, it bides its time to return, and, when vigilance is relaxed or the dynasty has perished, it silently resumes the throne from which it has been expelled but which it never abdicates.

It bears no blażonry of bloom to charm the senses with fragrance or splendor, but its homely hue is more enchanting than the lily or the rose. It yields no fruit in earth or air, yet should its harvest fail for a single year famine would depopulate the world.

No, those are not enemy trenches nor modern military fortifications you 
The Bluegrass Claims Its Own

see as you look out over the great central field. They are merely traps, pits, bunkers, cops and mounds of fifty-seven different formations, set to catch the unwary - and sometimes the very wary - golfer, and they add not only to the picturesqueness of the landscape but occasionally to the language employed by some of those who traverse it.

I should like to tell you what the farmers round about here really think of the game that engages the attention of so many of those who frequent the Club, to the exclusion of other matters of interest, but a fair statement of their views I do not think could pass the censor. If they were native-born American or English, Scotch or even French farmers they might and probably would stand for it, but as an intensely practical, hard-working, frugal, serious-minded folk of German descent they look upon the devotion of 160 acres of good grazing to such a silly 


\section{The Road to Dumbiedykes}

thing as golf as little less than an economic crime. Think how many cabbages those fairways might produce! Think of the onions that could be grown upon the heavily-fertilized and perfectly-irrigated putting greens! Count the cows that could be pastured upon the grass that runs to seed there every summer!

These Bremen township people, however, are not averse to taking what they can out of the place. The proper upkeep of the links involves the employment of many men and teams. The property is maintained at about the same expenditure of money as a city park of like extent. A complete water and drainage system is installed. Men and horses from the surrounding countryside are frequently requisitioned by the management. Not that there is always quick response; for there is not. The rush-time at the Club is commonly coincident with periods of unusual activity on the farms. 


\section{The Bluegrass Claims Its Own}

Corn-planting or cultivating, haymaking, the oat harvest or other field work at home prevents the average farmer-neighbor from selling service or power to anyone else. When they do work for a Country Club they of course charge all the traffic can be made to bear; which is natural, of course, and all proper enough. What good is a Club anyhow if those who deal with it as outsiders may not milk it?

And yet with all the sport these same thrifty people make of the big and beautiful links in their midst, and of those who play over them, I note that they themselves go in for some little recreation now and then. Pitching horseshoes at pegs in the ground is good fun. I have enjoyed many an hour at it myself when my lot was cast upon a farm. And it doesn't hurt these good German farmers particularly that I can see to indulge now and then in this competitive contest of skill. To win requires a steady hand 
as well as a good eye. The only objection I enter is that one so seldom sees them at it. They would be the better for more of that sort of thing, and their wives and cows and pigs and geese would not suffer either.

Every hard-working individual requires relaxation. It doesn't make any difference whether he be the owner of a farm or factory; whether he be wrestling with a working dairy in the country or a battery of type-setting machines in town. And golf has come to be the accepted physical salvation of those who are in heavy city harness.

Not every man whose business holds him to the city can afford to buy and assume the care of several hundred acres of favorably-situated, easilyaccessible land. And not all of those who could afford to indulge themselves in this luxury care to take on the added responsibilities that are inseparable from the attempted operation of an individual farm. But nearly every- 


\section{The Bluegrass Claims Its Own}

body can enjoy the benefits of those life-saving stations, now so freely distributed around the fringes of all our cities, known as Country Clubs.

Personally I have for years had a longing to possess a well-equipped farm, where I might busy myself trying to unravel some of the mysteries surrounding the perpetuation and modification of animal and plant life. I should want good horses, good dogs, good cattle, good motors, alfalfa, bluegrass and some mellow grain land. Also a good library, and a big, oldfashioned fireplace. And, above all, good friends who would enjoy it with me. However, I don't believe in a man's trying to ride two or three horses at once. I have had one in town that has demanded all my thought thus far, and so the farm still waits until such time as I may turn my back upon the city's work forever to end my days, as they began, midst rural scenes. 



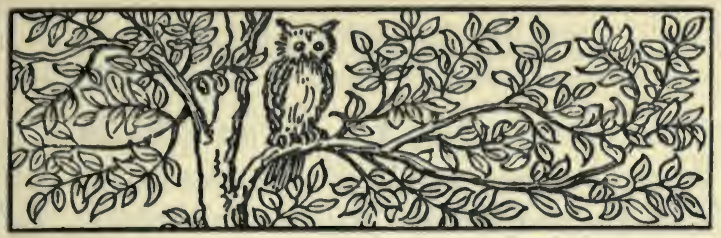

\section{CHAPTER V}

\section{Midsummer Night Alarms}

For many years Billy and the girls and I had been "doing" the summer resorts. Or, rather, the resorts had been "doing" us. In the early days we had been the rounds of the inland lakes. Two weeks was then about the limit of the time I could afford to spend away from work. We slept on hard beds, fought flies and mosquitoes, caught a few pickerel and pond lilies, had an occasional hayride, and went back to the city imagining we had had a wonderful time. These annual dog-day expeditions were gradually extended until we found ourselves at length at distant seashore or mountain summer places, the discomforts and expense increasing pro- 


\section{The Road to Dumbiedykes}

portionately with the distance traveled.

We wound up with a summer in Europe. Finally Billy threatened to break down under the strain of this sort of thing, and we viewed with equal alarm the thought of another summer in the "stuffy" city house or an outing at so-called resorts at home or abroad. It was at this juncture that I walked one day in the early spring through the edge of the Midlothian oaks, and that was the beginning of the end of one family's vacation troubles.

I took title to a wooded knoll that looked out upon a wide expanse of verdure, with nothing to impede the sweep of the prevailing southwest summer breeze, or mar the beauty of the sunset. We let the contract for a cottage-bungalow and barn, and ninety days later took possession. That was the third of August, and this is what straightway happened.

The first night in the country nobody could go to sleep; it was so [ 56 ] 


\section{Midsummer Night Alarms}

desperately still. A harmless little screech owl was trilling somewhere in the dark recesses of the grove. That was all. But it didn't sound a bit like the clang of the motorman's bell, nor yet like a Klaxon horn. If it had it would doubtless have sent us all into a sound slumber at once, so readily does one accustom his ear-drums even to the operations of a boiler factory running nights next door. We were tired, and had sought the pillows early. But first one and then another member of the household called out in protest against the infinite quiet of the night.

The katydids had not yet reported. Their date here is about the fifteenth of August, the month so dear to insects of high and low degree. That orchestra, therefore, had not yet commenced its rasping rhapsodies. And so the hours dragged their weary length along, until a white-robed figure presently put in a stealthy appearance at my bedside, by way of informing 
me in whispers tense that I must come with her to the open window and listen. There was a burglar prowling around somewhere in the yard! It was an old man, she knew, because she heard him cough! Now, just how it was figured out that our midnight intruder was well along in years I have never been able to make out. But, anyhow, the bronchial trouble, or whatever the inciting cause, presently induced another cough, which, from a one-time intimacy with "the lowing herd," I was not long in diagnosing as of bovine origin, and emanating from neighbor Clark's adjacent pasture. So, after an argument more or less drawn out, in the course of which my alleged knowledge of cows was called into point-blank question, I induced the flock to settle down again in search of slumber. Needless to say that after the mere suggestion of a housebreaker skulking somewhere in the lilacs, all slept with one eye and both ears open, 


\section{Midsummer Night Alarms}

and those who thus avariciously look for trouble frequently have little difficulty in finding it - or that which serves the same purpose.

For what seemed an eternity of time naught but the ticking of the clock, the chirping of crickets, the distant barking of a dog or the drowsy call of some restless chanticleer on a neighboring farm broke the deep silence of this our first midsummer night in the depths of the real country. When the solitude was disturbed, however, it was broken properly. Suddenly, and without warning of any kind, there was a rush and a roar, followed by a desperate crash on the floor below! The shock upon nerves already over-strained may be better imagined than described. All hands - or rather feet - hit the floor at the same instant. What was it? What dreadful thing had happened squarely within the cottage walls? Probably the burglar had fallen headlong over a piece of furniture! 


\section{The Road to Dumbiedykes}

Anyhow, I reasoned to myself, he had never intended any such demonstration as that, and unless he had broken his neck in the fall he had doubtless made rapid tracks in the outer darkness for tall timber. And so I mustered up courage for a frontal attack upon an ambushed enemy.

Backed by all the females in the house - we had no boy to send to the front - I made a cautious descent into the darkness below, bearing a lighted candle. What better mark a burglar could desire I am at a loss to suggest. The last step was safely reached, however. Somewhat to my own disappointment I had not yet been shot. Moreover, as yet I saw nothing to shoot at myself. Everything was in order, just as we had left it on retiring for the night. The doors were all closed, and the locks had not been sprung. Ditto the windows. All was mystery. But, let us think a moment! Before closing up 
for the night Billy had carefully drawn down all the new and lively-running shades. Of that she was certain. But, see here! One of these is now up tight against the roller at the top of the casing! We breathed again. The case was clear. At the psychological moment, after the household had been worked up by the episode of the coughing cow to a keen sense of impending danger, this shade with a powerful spring had taken upon itself the responsibility of flying up in the dead of night at the full limit of its utmost speed. I never knew that one of these rollers could cause so dire an explosion. But in the still watches of a noiseless night the drop of a pin is sometimes as the fall of a brick.

A neighbor across the way also had some nervous members of his household, and proposed some time later that it might be a good scheme to put a night watchman on the job. As it seemed to be a case of "women and 


\section{The Road to Dumbiedykes}

children first" I readily acquiesced, and a steady-going fellow, with good references as to his personal character, was duly employed to scout all night through the shadows of the surrounding oaks. $\mathrm{He}$ was of course duly armed, and a sense of safety immediately pervaded all the neighborhood. Unfortunately we had not taken the trouble to get references as to the amount of gray matter carried under the new watchman's hat. $\mathrm{He}$ was a serious-minded German, and, as now develops, with little sense of humor in his mental makeup.

The last thing we would hear at night would be his reassuring tread upon the grass, or down the road. He did not sleep on the job. That seemed obvious. Of course we did not lie awake all night to make sure of that fact, but about a week after we put him on the watch we had proof that he did keep going after we were safely launched. 


\section{Midsummer Night Alarms}

A revolver shot, followed by a second and a third, rang out loudly on the midnight air not fifty paces distant in the border of the wood. Although somewhat dazed and startled when thus rudely wakened, we thought it all over, and concluded that Hans had ro doubt gallantly routed some marauder who was threatening our peace and safety We heard nothing further, and, after first congratulating ourselves on this proof of our own prudence in arranging for protection, decided to wait until morning to hear the story. The night passed off with no further alarm.

"Well, Hans," I asked next day, "what was the trouble last night? Did you get your bird?"

"Oh, yes," he rejoined, "I got him." "You did? What was it? Tell me all about it."

"Well, you see, efery night dot owl he come into dot tree. He stood there looking right at me with both his eyes. 


\section{The Road to Dumbiedykes}

And now I got him." And he grinned as he reflected upon what he merely considered convincing evidence of good markmanship such as should be valued by an appreciative employer.

I will lay a wager now that this fellow hasn't figured out yet why he was not retained to watch over our slumbers, and has not yet recovered his equanimity at being discharged upon the spot as an impossible "fathead."

These experiences of the cow with the cough, a window-shade running wild in the middle of the night, and a watchman with no targets but innocent owls in the trees, afforded about all the evidence necessary to establish our complete confidence in our further security. So we began then and there to laugh at fears, and put on flesh; and now we no longer lie awake or get up and seek the cause of any disturbance whatsoever between the sunset and the morn. 


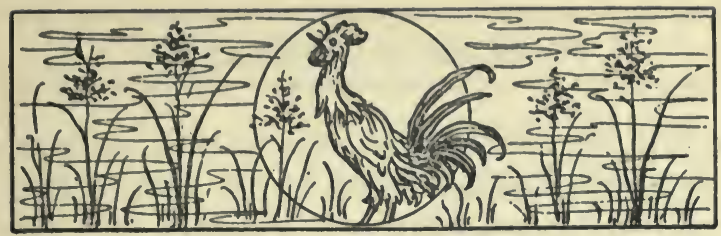

CHAPTER VI

The Coming of the Dawn

No painting of its type appeals more powerfully to my imagination than Guido Reni's Aurora strewing flowers before the chariot of the sun god. The only trouble about it is that it is a ceiling painting; but opposite the entrance of the Casino Rospigliosi just off the Via Quirinale, where this great mural triumph may be seen in Rome, there is a table upon which you will find a hand-mirror in which the marvelous coloring may be studied with more or less satisfaction. And that reminds me of a little story of the Sistine Chapel.

Some years ago Billy and Bess and I were in a Baedeker brigade ostensibly studying, with the aid of little mirrors 


\section{The Road to Dumbiedykes}

supplied by the custodian, the inspirations of Michael Angelo on the ceiling of that world-famous chamber of the Vatican. I was of course deeply impressed by the majesty of the great master's conception of the Creation, the Fall from Grace, and the Deluge, and turning to call the attention of Bess (aet. I6) to the marvelous effect produced in certain figures by foreshortening, I saw to my amazement that she was apparently taking no interest in the proposition whatsoever. Just why I should expect a schoolgirl in her teens to go into ecstasies over these dingy old religious pictures I do not know. But, making no allowances for the difference in our ages and point of view, I only saw that she was busy primping, with the aid of the little papal mirror in her hand, and not looking at the ceiling at all. Now to me this seemed, if not just sacrilegious, a bit frivolous, and I said somewhat testily, I fear:

[66] 


\section{The Coming of the Dawn}

"My dear girl, do you imagine I brought you four thousand miles to this famous place merely that you might adjust your bangs here in these Sistine Chapel mirrors?"

Needless to say, Billy came to her rescue, even as Biddy rushes to the defense of an assaulted chick, and I was duly humbled. I have always believed, and believe now, that they were both doing the same thing. In fact, I will go further and assert it as my opinion that fully fifty per cent of the female visitors in the chapel that day and probably every other day before and since - only need powder puffs, furnished by the guides, along with the hand mirrors, to convert the Sistine Chapel into a popular beauty shop.

Well, anyhow, to see the Aurora's glowing glories you perforce must use a mirror. It is the one painting in Europe I should like to own and have under my own roof, but there is at least one reason why that is scarcely a 


\section{The Road to Dumbiedykes}

feasible proposal. However, I have consolation in respect to that. I can show you any May morning from the casements of Dumbiedykes the original of Guido Reni's inspiration. It, too, is a ceiling proposition; a picture projected first but very faintly upon the dark canvas of the waning night, but developed across the great blue vault with such a subtle turning on of lights that for the space of perhaps an hour you will be truly spellbound in the grip of the eternal mystery that precedes the final dazzling advent of Phoebus Apollo himself in his car of fire.

Probably you had rather sleep. Well, so had I, as a regular procedure, but out at Dumbiedykes we are apt to retire not so very long after the feathered tribes have settled for the night. Nine o'clock often finds us in our nest, but I have discovered that as the world grows older I do not seem to require as much sleep as in earlier times. There is [68] 


\section{The Coming of the Dawn}

that brown thrush in the barberry hedge. She turns in every night as soon as the darkening shadows begin to fall across the lea, and stirs not at all again until the sunlight calls her forth to her accustomed tasks. I am no thrush. I can and would get up frequently with the fabled lark if there were any around, but the much-touted species of song and story does not register at Midlothian. And so it sometimes happens that I awake long before the first gray tones outside have given silent notice of the passing of another night, only to find that there is no sign of life in air or sky but one - the crowing of the roosters on the neighboring farms.

Theoretically, Chanticleer is supposed to announce the onset of Aurora and the Hours. Practically, he does nothing of the kind. Evidently he suffers terribly from insomnia. Not only that, but he seems to have little consideration for the faithful spouses 


\section{The Road to Dumbiedykes}

by his side on every hen-roost. In brief, the owl of world-wide nocturnal celebrity has little on the gallinacious male. Roosters may settle down amidst their wives for a time. Possibly they may stand it until after the midnight hour has struck, but after that let any one bird in any old place in any community where poultry abide send out his challenge, and it's all off at once, so far as the further keeping of the peace in the henneries of that particular neighborhood is concerned.

I once spent a short vacation at Bon Air in the edge of the beautiful little city of Augusta, Georgia, and I am prepared to assert that nowhere else in all the world-so far as my experience in two hemispheres extends-are there so many roosters working on the night shift and overtime as in the suburbs of that winter capital. Why these Augustan cocks kept up their clarion calls so lustily and persistently I never knew. Possibly there was a [ 70 ] 


\section{The Coming of the Dawn}

tacit agreement that it was poultrywise, in that particular part of Dixie, to have as many sentinels on duty as possible through the dark time. Maybe the rivalry for the honor of heading the various establishments in that region was for some reason or other especially keen.

I was told by a lady, upon the occasion of a visit to Belgium some years ago, that the women who go to the fairs or markets in Flanders to select male birds for breeding purposes base their choice wholly upon the relative strength of lung power - ergo constitution - as evidenced by the crowing of the cocks in competition, the birds with the most vociferous, longdistance voices being universally sought. Anyway, if you ever go to Augusta and hear one long drawn-out call in the far distance, answered first by one and then by another bird until about fourteen thousand join the swelling chorus, the challenge passing 


\section{The Road to Dumbiedykes}

completely around the deep amphitheatre of the southern night, I pray you do not make the mistake of assuming that it is necessarily time to get up, for probably it isn't.

I wish someone would tell me why a rooster crows at all. What is his idea about it, and what do you suppose staid old Biddy there alongside him on the roost thinks of his night messages down the line? I have often thought that if I were a hard-working hen, after scratching and traveling in barnyard, field and garden all day long, making my own living and that of a greedy brood of youngsters beside - and that too with precious little help from the grandiose old rooster - I would draw the line on this hooray business between midnight and the dawn, and if sitting within reach would give him a peck he would not soon forget. If the whole disturbed sisterhood would take a hand in such chastisement surely the head of the household would be 


\section{The Coming of the Dawn}

beaten into making terms. From the fact that they do not do so I infer that the old girls rather like these nocturnes in all sorts of keys, or at least become indifferent to them, otherwise they wouldn't stand for them. I suppose that some of "the younger set," the pullets, with life still largely in the future, may perhaps find sweet music in those mighty efforts, but the matrons of the flock surely must weary of them ere daylight comes to cut the crowing short.

Having shown that there is not necessarily any real relationship between Aurora and the roosters, let us now assume that it is say 3:30 A.M. of the I5th day of May. That dog over there on the old Rippet place is barking about something concerning which he probably knows nothing, but apart from that peace reigns. Unseen hands have already been busy, however, setting the stage for the transformation scene about to be enacted. The stars 
have lost their sparkle. Through gradations imperceptible to human sensibilities, the sable hangings of the night are silently shifted westward on the wings of the morning breeze. The world is still asleep; terrestrial animation apparently suspended - excepting always in the henneries. Out of steel-gray shadows now emerge faint outlines of familiar objects in the landscape. In the east thin shafts of a light impalpable pierce the dissolving gloom. In the far west a bank of purple follows the retreat of night. The plaintive cry of a hungry lamb is heard, and again that dog at Rippet's! I know perfectly well that the trees and bushes all around are full of tenants, all but ready to burst into their May-morning song, but as yet no sound reveals a single bird.

I do not have the temerity to wake up the rest of the household to ask them to study with me the beauty of the now onrushing dawn. I once tried 
to get Billy out from a closet in which she had taken refuge, while I went into raptures over the Satanic blazing grandeur of à wild electric midnight storm. She loves Nature too, but not in her (Nature's) wilder moods, nor yet at 4:00 A.M. Had I asked that she join me in watching the earth awake, I should probably have been requested, with more or less graciousness, to look at the spectacle as long as I liked myself, but to please allow her to get her morning nap, and mail my account of the performance later, if I liked. And so I sit alone.

On the stroke of four a crow caws down there in the timber by the bridge; whereupon a robin from some secret place about the lawn indulges in a drowsy chirp. Some other morning this sleepy note from somewhere underneath the window may precede the call of the big black brother in the woods. In fact, sometimes one starts the ornithological breakfast ball about 


\section{The Road to Dumbiedykes}

these premises, and again the other; so I do not undertake to rank the order of their rising. I only know that both prepare to begin the operations of the day before any of their nesting neighbors have given any outward evidence of intent to go to work. It is surprising how immediate is the response of the other crows and robins to the initial caw or chirp. The crows are at once alert and scolding vigorously. That is, it sounds like scolding. As a matter of fact, I presume Mrs. Crow looks upon old Jim's voice as the best in the community, and what seems to us a family row is but the expression of a real Corvine affinity.

Cock Robin does not launch himself at once into the cheery roundelay for which he is so famous, and yet he does not indulge in any extended prelude to that finely-finished performance. $\mathrm{He}$ just tosses off a few disjointed fragmentary notes by way of testing out his tubes, and then springing for- 


\section{The Coming of the Dawn}

ward to the center of some convenient stage releases that resounding reveille that serves at once as love-song, call and challenge. And how quickly all his kind join in to swell this morning carol to the dawn! Mind you, the sun is not yet risen. Robin does not wait for that. Neither does the turkey gobbler. The "turk" is one of the very early birds, and Tom loses no time in trying to impress his importance upon the farmyard population. About the same time that the robins wake, your gobbler spills a series of those bronchial ebullitions, the like of which is not to be located elsewhere in the entire realm of vocal acrobatics. Just why such really beautiful birds as the turkey and the peacock should have been condemned to walk the earth with such ideas of music in their silly heads presents one of the unsolvable riddles of creation.

In a hollow in the oak the flickers have a nest. Roused by the robin's 


\section{The Road to Dumbiedykes}

call, a sleepy little head now appears in the aperture; eyes blink, and the owner settles back out of sight undoubtedly for forty more blessed winks. An empty wagon is rumbling down the road. Clark's calves are bawling for their breakfast. Evidently the farm hands are stirring somewhere for in the distance pigs are squealing. I know that note. It calls for corn. Hello! Again the flicker's face, framed in solid oval oak. This time the bird is fully roused. She perches for an instant in the entrance to the tree's interior, yawns, and takes an observation. Although I am but a few arm's lengths away, she does not know it, or if she does gives no sign of interest. She looks first up, then down; now sideways, then hops out, clings for a moment to the rough tree trunk, then wings her way to where she knows a good fat grub-worm waits.

About 4:15 a mocking bird perches on the topmost branch of our tallest [ 78 ] 


\section{The Coming of the Dawn}

tree, and the song service to the rising sun is on in earnest. Easily the leader of all that company in point of persistency and sustained sweet flow of full-throated melodies, his accompaniment is played in riotous confusion by bluejays, cat birds, robins, sparrows, crows and thrushes, and on the roof the redheads pound the drums. While all this is at its height, across the greenery of the fields the first long horizontal rays announce the advent of his flaming majesty.

From out the cover of the hedge now comes gray Molly Cottontail. She stops, looks and listens warily, and is on her dainty way. And then a strange thing happens. As suddenly as it all began the celebration stops. By five o'clock all is as silent as before the first crow cawed. The singing ceases. The choir as an organized body has been dismissed. What does it mean? Breakfast. Everybody busy. That's all. 



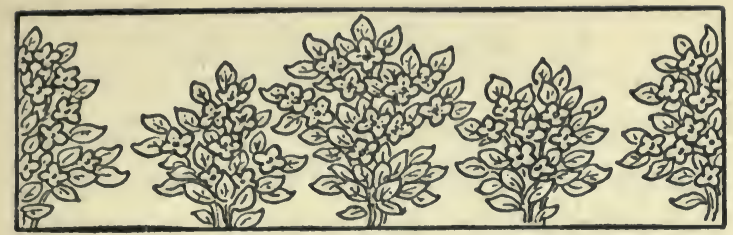

\section{CHAPTER VII}

\section{Dumb Walls}

Some places fairly name themselves, some are christened simply. by their owners, while still others have their titles thrust upon them. It is to this latter category that the naming of the cottage Dumbiedykes must be referred.

Away down upon the western shores of the Gulf of Mexico the old town of Corpus Christi lies in the sands awaiting the future. It really has a past that is full of interest, but the world for the most part hears little and perhaps cares less for the ancient settlement. You are here upon the edge of a famous cattle country, but a range giving way rapidly now before the advance of the man with the hoe and the drainage ditch. A little way in 


\section{The Road to Dumbiedykes}

the north you would strike the famous ranch of Charles P. Taft, property of the brother of our worthy and most outrageously maligned ex-President. Far in the south where the Nueces enters the great gulf is Santa Gertrudes, the 2,000,000 acre ranch under the clever management of Robert Kleberg, son-in-law of the late proprietor, Captain Richard King of ante bellum fame. In the west you will not have far to drive before you will come to the entrance gate of the Rancho de los Laureles, late the property of the Texas Land and Cattle Company, and, in the hands of that corporation under the supervision of a canny Scot, one Captain John Todd.

You are here in a land of magnificent distances. This Laureles Ranch has in recent years been sold to Mrs. King, and added to the royal domain of Santa Gertrudes which it adjoined along the Nueces boundary; but at the time Billy and I visited it some years 


\section{Dumb Walls}

ago the Todds were still in control and lived upon the ranch in a long, low, rambling one-story headquarters situated some ten miles from the front gate. These great properties under fence were really like principalities in the old world, presided over with an iron hand by the owner or manager, with the aid of course of a Roman Catholic priest to teach and confess the numerous Mexicanos constituting the help universally employed indoors and out. Quite a town this Laureles at the time of our visit, with its assembled tenant houses, church, stabling and the various buildings and corrals usually to be seen about the seat of power on a modern cattle ranch.

Here remote from civilization, long leagues from any neighbors, surrounded as far as eye could reach by the dead level reaches of enormous pastures, where the coyotes called about the house at night, and rattlers were a common sight, Captain John Todd, an 


\section{The Road to Dumbiedykes}

educated Scot, and his wife, Patricia Clay, of gentle Border birth, lived in comfort and dressed for dinner every night. You can't deny a Briton-born his "tub" or his dinner coat no matter where you may maroon him. He will cling to his inherited habits in spite of all and any ordinary obstacles. And so we spent, once upon a time, a most delightful holiday as members of a jolly party at this hospitable ranchhouse of the southeast Texas plains. There were long gallops on the ponies, or rides in the "ambulance" by day, and "doings" every night. Five o'clock tea came in between of course. But as darkness settled down upon the range there came the glow of lamps, the radiance of ladies in evening dress, the cheery tinkle of cracked ice, good service, a famous dinner, coffee and cigars, then music, singing, maybe dancing, or charades, and at last "good night" out on the porch beneath the brilliant southern stars! 


\section{Dumb Walls}

It was during one of these Olympian evenings that the hostess asked us what name, if any, we had chosen for the house we had been building in the new Midlothian. Upon being advised that the little place was nameless yet, she said at once: "I have it - 'Dumbiedykes'!" and then my Scott came back. I had but to recall one of the opening scenes in "The Heart of Midlothian." And yet I asked, "Why 'Dumbiedykes'?"

"Well," Mrs Todd replied, "You know in Scotch a dyke is a wall. Dumbie (pronounced dummy) dykes would be dumb or silent walls. You will have friends and boon companions with you often. Many good times will doubtless be enjoyed. Dumb walls tell no tales. What name more apropos?"

And then and there I was duly made to kneel and receive a special christening as the "Laird of Dumbiedykes," a patent for which title, duly signed and 


\section{The Road to Dumbiedykes}

decorated with varicolored officiallooking seals, was duly issued by the mistress of Laureles Ranch, and the same now hangs upon the said dumb walls of Dumbiedykes, where those who may question the correctness of this weird tale may have all doubts as to the regularity of the procedure quite removed.

Scott's old Laird of Dumbiedykes possessed one trait only, so far as I can figure out, to which I should care to lay any claim whatsoever. On his deathbed he said, among many other things, to "Jock," his son and heir:

"Jock, when ye hae naething else to do, ye may be aye sticking in a tree; it will be growing, Jock, when ye're sleeping."

Many is the tree and shrub I've "stuck in" during my time at the Brick House farm. You may find them on the lawn. One in particular, a Rocky Mountain blue spruce, of which I am very fond. The spireas [86] 


\section{Dumb Walls}

in that circle where the automobiles turn and the fancy sumac in the centre; the dogwoods and the willows by the creek; the Rosa Rugosas along the south front of the Mansion House. Yes, and they have grown, sure enough, while we all have been asleep, and now add a little something to the total sum.

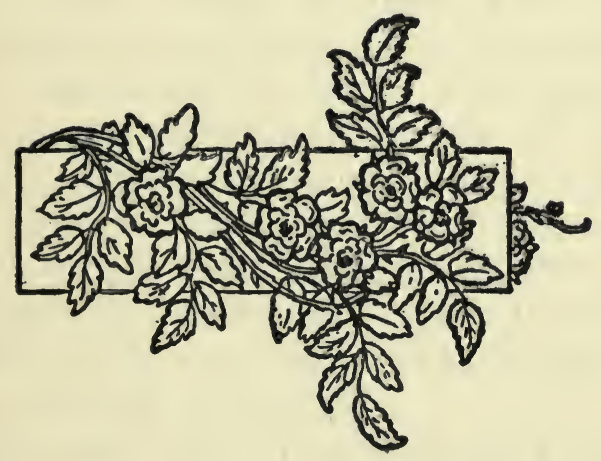





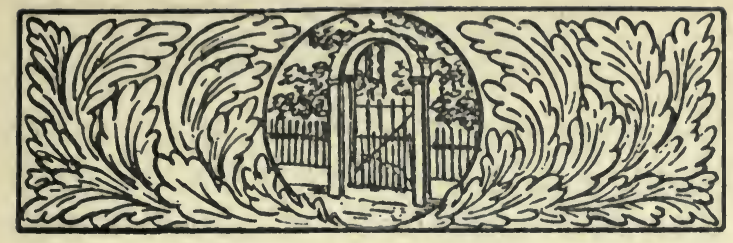

\section{CHAPTER VIII}

\section{The Garden Gaté}

I am finishing these notes under the shade of one of the oaks that seduced me into making the original drive for personal liberty and privacy during the heated term. Fussing with her pansies there is Billy. You who knew her just before we found this retreat in an out-of-the-way corner of the world would not know her now. She was always fair enough - at least to me - but the fact is she is now flirting desperately with two other $f$ 's, for which two g's - golf and gardening are primarily responsible.

Since my earliest recollections I have ever been fascinated by the first forecasts of spring as evidenced by vegetation. I knew where the peonies and 
bleeding hearts were making ready underneath dead leaves to send up their first red signals of a life resumed. And as the melting snows started into activity the drains and ditches that had their sources hidden in the woodlots, day after day I followed the flowing water far afield. Great journeys have I taken upon those occasions, engrossed intensely in the fortunes of chips or sticks that I had launched upon the rushing currents. Many a disaster, too, I have witnessed on those flood waters of the early spring among the pussy-willows, before the little boats could find safe anchorage in some quiet pool below the rapids. Aye, and I have seen some shipwrecks since, in the broader stream of human experience; and decidedly more tragic.

When the color begins to deepen on the dogwoods late in March a subtle something tells me I shall soon be headed down the road to Dumbiedykes. And when we first haul up at [ 90 ] 


\section{The Garden Gate}

the garden gate the one green thing to greet us there each year is the neverfailing Iris. In Greek mythology the name was borne by the swift messenger whose service rendered Juno was identical with that of Mercury to Jupiter and her flight as she did the bidding of the goddess queen was marked by the rainbow in the heavens. Our modern Iris waits not, however, the appearance of April showers, but rises like the crocus from its bed of snow, bringing to a waiting world the welcome message that the spring is here. Fleur-de-lis, native lily of the low-lands, the improved varieties of Iris, both Japanese and German, produce their feathery plumes of gold and purple while yet their tardy sisters sleep.

A few real native bluebells make their home underneath the oaks, putting out their pale blue pinkish blossoms, and departing before the trees above them waken from their slumbers. 


\section{The Road to Dumbiedykes}

The lilies of the valley fabricate their tiny little cups, and resign themselves quickly to the business of rootmaking for another season. And while these busy early risers are heralding the coming of the great procession of the floral year, the flowering shrubbery is not lagging.

The hedge of Japan quince can always be depended on for its charming rose-red blossoms, put out simultaneously with the dark green foliage. Lilacs of course. Graceful and sweet are the improved white and Persian sorts in favored localities, but the old vulgaris cares so little where you ask it to ply its beneficent vocation, as hedge or clump or single specimen, that I love it as I do an apple tree for its astounding sturdiness.

Around the doorway we planned to have a snowdrift in the month of May. There is of course but one way to this - the spirea Van Houttei or bridal wreath; and in all the world there is [ 92 ] 


\section{The Garden Gate}

no fairer sight than great banks of this at flowering time. As cover for the fence along the road we chose syringas - the mock-orange of our youth - various varieties, all hardy, vigorous, pure white, some highly scented and growing to fine stature. Two of these planted near the east wall of the cottage have reached the eaves above the bedroom windows on the second floor, and nod a sweet good morning to our guests.

Along the front we wished a hedge that would turn back anything and yet be highly ornamental, and we have it. I defy any ordinary creature to make its way through my Berberis Thunbergii in its twelfth year! No winter is too cold for it! No summer too hot. It is a thing of beauty and a joy forever, except to those who may court undue familiarity. Fern-like foliage from May until October when the first frosts paint it like the rose, and scarlet berries pendant on each thorny branch until forced off in April

[ 93 ] 
by new growth. Wild crabs have we also in one corner; and their early blossoms bear me back to woodland thickets of a long ago. The rose unfortunately does not well in this particular soil and environment, but we have a small success with baby ramblers and sweet, tall Dorothy Perkins. We of course depend upon the annuals mainly for the cut flowers, which Billy loves to see in every nook and corner of the cottage throughout the summer. Formerly I used to spade the beds and sow the seeds in the open about the 25th of April, and some famous displays of phlox, petunias, zinnias, marigolds and snapdragons we have had, but never again! The weeding is as back-breaking a job as extracting dandelions from the lawn, and the waiting for the flowers seems a waste of time. I patronize the man with a greenhouse now, and at some added cost have earlier blooms and fewer aches. 


\section{The Garden Gate}

I have a weakness for lilies, and the auratum and speciosum have given us some truly wondrous flowers. The gladiolus and the tuberose are also always given place. Likewise asters, salvias and cosmos. A patch of golden glow is running a race against a bed of real red-stemmed Kentucky mint. I don't know which spreads the faster or which finds greatest favor after being picked. This thing I have observed, however, that the two seem to go logically together.

To tell the truth, the little garden is all too small at best, and is shaded too by oaks which were once even more numerous than now. These have grown some since the night that window-shade blew up, and the axe has been put to the roots of a few condemned. I suppose I dislike as keenly as any Druid of old to see a tree felled. I worship them, but there is a fine old fireplace in the house, and when the days are cold or wet the chimney- 
breast becomes the altar upon which something must be sacrificed to the household gods. Our oaks are not such stately ones as you may see growing out of deeper soils. The black ones are already gone, and the gnarled limbs of a group of burr oaks speak plainly of the struggle they have had with their feet standing in a clay as hard as iron.

Upon the plastered outer walls the ampelopsis Veitchii spreads its dainty tendrils, and now and then yields up the ghost unto our savage winters. On the north walls it will be all right, but a southern exposure encourages it too late in the autumn, and rather too early in the spring, for its own good. On the garage the unkillable woodbine flourishes unrestrained. This particular Virginia creeper has caught the electric light wires in its grasp, and is slowly but surely traveling across the lawn upon a support which apparently is stimulating. 


\section{The Garden Gate}

All this affords not only cover for ourselves and buildings from the outer world, but here too the native song birds love to come and build their nests and rear their families. I know them well, and we get on famously together - making common enemy of course of that "rat of the air," the English sparrow.

My daily pathway takes me through the grove, and here is God's own garden; wood violets and arbutus, sorrel and "shooting stars," crow's-foot and spiderworts of royal hue. Here, too, May apples and wild strawberries bloom; and amidst it all the bluegrass encroacheth ever as the underbrush is cleared and the oaks depart.

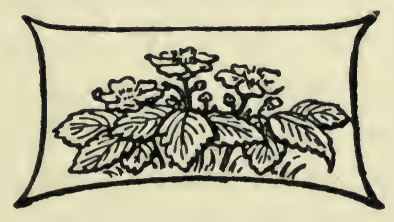





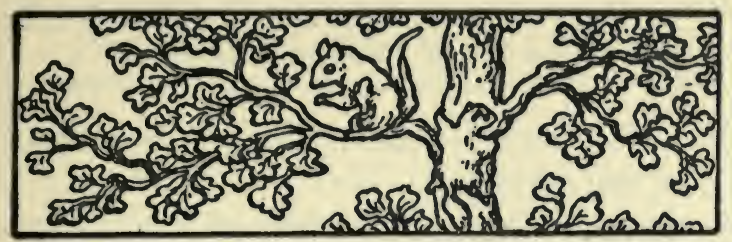

\section{CHAPTER IX}

The Tragedy of the Flying Squirrels

There has always been something more or less pathetic to me in the passing of big black oaks. They do not belong to a long-lived family. A fine specimen once stood down near the foot-bridge just below the dam, and when I first knew it old age was slowly but surely creeping over it. The once handsome, wide-spreading top was no longer proudly carried nor symmetrical. Dead branches announced impending dissolution. Forest sclerosis had clearly set in. It was hollow, too, at the base, and many a hard-pressed little creature of the wild had here found safe sanctuary from hot pursuit. It was in this aging monarch of the grove that I first saw the happy pair of which 
I write, and I deal with fact throughout, not fiction.

It was during those first alluring days of mystery when, answering the call of the south wind and the April showers, the violets had forced their way through the dead leaves and other vegetable detritus, the accumulations of the winter in the wood, when all that brave company of oaks - white, burr and black - had taken on those infinitely delicate grays and greens and browns that are the despair of artists, and mark the early stirring of the blood in arboreal arteries.

The flying squirrel, so-called was once a common object in and about our mid-west timber lands, but it had been many a long year since I had seen one, and we rejoiced accordingly at a discovery which added such a distinct attraction to the leafy precincts through which we walked daily to and from the cottage. The crows, jays, woodpeckers, cat birds, thrushes, [ 100 ] 


\section{The Tragedy of the Flying Squirrels}

robins and the rabbits were all old friends that never failed us, but the addition of these two tiny aviators of the woods to our regular summer colony was quite the event of an ever memorable season. Whence they came nobody really knew. I dubbed them Hansel and Gretel. Some mother must of course have sent the little wanderers from some far country into this remnant of a once extensive forest, and here they were seeking, like the children of the old-time fairy tale, nuts, berries and adventure. Here, too, like the babes which the genius of Humperdinck has immortalized in melodious opera, they were destined at last to be overcome by the spell of an evil genius - one vastly more powerful even than that of the fabled witch of the Ilsenstein. Indeed, they fell into a sleep at last from which they have not yet awakened.

They seemed to have no fixed habitation as the season progressed, but 


\section{The Road to Dumbiedykes}

leaped from oak to oak and frolicked in the foliage with that joyous abandon that knows no fear and has no care. The steel of fate had yet to be experienced. Great is youth and hope and. innocence! Pure and undefiled the happiness that has yet to face the future.

Shelley's "Ode to the Skylark" is the loftiest of all hymns to the outof-doors. It exalts the sympathetic spirit to the "blue deep's" most immeasurable heights. I often fancied as I watched the mad antics of the flying squirrel that he, too, was in reality

Like a disbodied joy,

Whose race is just begun.

The audacity of this pair was something appalling to one unfamiliar with their inherited accomplishments. It was always a question as to which could jump and soar the farther, and they preferred ever the leaps from the topmost branches of the tallest trees, the [ 102 ] 


\section{The Tragedy of the Flying Squirrels}

passages attended by the greatest apparent risk, with fine contempt for the distance to be traversed. Surefooted and swift as an arrow from the cord, they shot back and forth from one leafy canopy to another. And so the golden summer passed.

I think they came to know me at last quite as intimately as I knew them. To my way of thinking all created things are more or less akin anyhow. The lives of all certainly present too many parallels to admit of any other hypothesis as to the universal fellowship. To be sure we count ourselves the ruling race. If might makes divine right then we surely read clear our title to domination, but in our appetites and habits, our ambitions and anxieties, I have seen as yet little difference in any fundamental as between the different forms of animate existence. Man hungers and feeds himself like any beast of the field. $\mathrm{He}$ has thirst which he quenches as does

[ 103 ] 
the bird at the brim of the brook although not always with the same good judgment. That which dear old Montaigne sets down as the greatest of all human pleasures is duplicated all day long in the billing and cooing to be seen in any dove-cote. All mothers have the same instinctive love for their young, and the little life of all alike is "rounded by a sleep." Beyond this we know naught. To be sure we humans have our faith in the life beyond. So has "Bob White" down there in that lower field, also, for aught I know.

Well, anyhow, we grew to be good friends. Just why they came, as fall approached, to seek winter quarters in the lawn at Dumbiedykes we shall never know. Possibly they recognized me as a brother. I do not know. If by any form of telepathy they could read my thoughts and sound my feelings toward them, I am sure that they would have known that they would 


\section{The Tragedy of the Flying Squirrels}

indeed be welcome to occupy an apartment that we had always in offer for furred and feathered folk in a scraggy burr oak tree that stands not twenty feet from my bedroom window.

I fancy that the original architects of this apartment, which had been beautifully worked out, were some of the woodpecker people. It was there when we acquired the place, and is there yet, and it has had many tenants in its time. The flickers, yellow hammers or golden woodpeckers, by whichever term you may please to call them, hatch out a noisy brood there every spring. However, when the first heavy frosts set the acorns clattering to the ground, Hansel and Gretel came along, looked over this vacant flat, and liked it. At any rate, they took it, and moved in, although not without strenuous opposition from a somewhat surprising and, I apprehend, quite unexpected quarter. It was by the merest chance that I happened to wit- 
ness a pitched battle between a husky and decidedly belligerent redheaded woodpecker and poor little Hansel. From the cottage window opposite I watched the fight. Just what object Mr. Woodpecker had in trying to serve a writ of ejectment upon the flying squirrel, I am sure I cannot tell. He did not own the place, and to my certain knowledge had never even asserted a claim to it. No redhead had nested there in all the years that I had possessed the property. I can only attribute his antipathy to the squirrel to the fact that probably some ancestral redhead had at no slight cost of time and labor made the original excavation and this loyal descendant was moved by some inherited instinct to protect its desecration in his eyes by a member of the ancient and not always respected family of rodents. $\mathrm{Be}$ that as it may, he undertook to storm the works, and much to my personal satisfaction was at length obliged

[ 106 ] 


\section{The Tragedy of the Flying Squirrels}

to retire discomfited. The valiant fighter in the trench had made a successful defense.

This I am sure was the flying squirrel's first real rough experience. What to us appeared a most amusing performance was to this dainty creature a real fight for life. With his back to the wall, his head was just visible in the aperture in the tree. Mr. Redhead, clinging to the rough bark just outside, went after the intruder with all the force that these marvelous little winged carpenters put into their telling blows. I fancy the squirrel was quick enough to dodge these attacks. $\mathrm{He}$ could not have withstood even one of those vicious jabs with that terrible beak, and the brave little fellow not only stood his ground inviting this punishment, but actually assumed the aggressive at times. He was evidently a finished boxer, for he led first with his left and next with his right with such swiftness of attack that he must 
have landed frequently on the woodpecker's face. Those needle points on the ends of his tiny paws were admirably calculated to scratch out an adversary's eyes. And so, after as pretty and as lively and as strange a set-to as I have ever witnessed, the bird gave up trying to force this Dardanelles, and winged his way back into the depths of the wood whence he came, leaving the flying squirrels masters of what was to be their winter home. And here we bade them farewell when we closed the cottage and returned to our quarters in the city.

Longfellow's description of the "cold and cruel winter" fits well the conditions that now overtook the last of the race of flying squirrels in Midlothian wood. Heavy snow and ice coated all the countryside, the mercury sank to almost unprecedented depths and it seemed as if the sun would never again return to release the northern earth from the iron in which it was bound.

[ 108 ] 
The Tragedy of the Flying Squirrels

But at last one day, after many weary weeks, a breath of spring was wafted from the Gulf, and the frost's relentless grip relaxed. The melting ice began its long journey to the distant sea, and we went out to make our customary preliminary survey of the premises to see how everything had endured the strain put upon vacant property by the rigors of a winter of almost unparalleled severity.

The cottage is carefully boarded up each autumn, and upon our arrival this particular day in March we found everything apparently just as we had left it. Inside all was cold and dark. There had been no heat in the place of course for more than three months, and the storm-doors and windows kept out every ray of light; so we perforce inspected the place with the aid of candles. In accordance with our usual practice, the large rug in the livingroom had been rolled up and shunted to one side. We had found in previ- 
ous years that little Mistress Mousie sometimes builded nests for herself and family in upholstered furnishings or other places that promised to be "comfy," from a mouse's point of view, and so we unrolled the rug that was to reveal a tragedy. Stark and stiff in death inside this roll we found the poor emaciated little body of one of the flying squirrels - starved and frozen in a desperate attempt at selfpreservation in the face of impossible conditions; and a half-hour later on the lawn, outside, underneath the very tree that had been so courageously defended in October, we found that the melting snows had uncovered the body of the mate!

How the final separation had occurred, how one had found its way in its dire extremity inside the house and far into the folds of the rug, are questions not to be answered this side of flying-squirrel paradise - if there be such a place. 


\section{The Tragedy of the Flying Squirrels}

The bodies were buried in the garden where witch-hazel branches overhang their grave, for they were not separated at the last; and, as head-gardener at Dumbiedykes, I can testify to this one fact that, although this all happened many years ago, wild violets have ever since sprung perennially from the ground wherein they sleep.

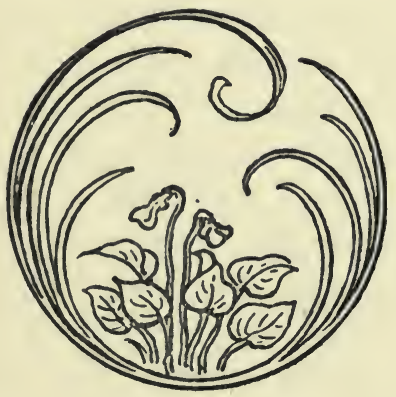





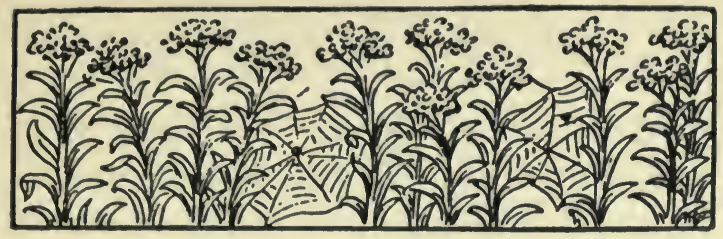

\section{CHAPTER X}

Toilers and Idlers of the Shining Hours

I profess no special knowledge of entomology, but at different times I have become for short periods intimately acquainted with certain individual specimens of the insect world. A honey bee which I inadvertently picked up from off a white clover blossom on the links one day in August certainly gave me a live enough time, for the few moments that he lasted. But I finally got him just below my knee. That was not half so "spooky," however, as the incident over on the thirteenth hole where after a heavy rain, while the surface water still soaked the fair green, an ill-fated and good-intentioned frog leaped into trouble up a player's trouser leg. The 


\section{The Road to Dumbiedykes}

reader will of course not infer from this that I am classing batrachians as insects. Far be it from me thus to insult the vastly more intellectual bug creation.

Speaking of bees, one day last summer a swarm from off some neighboring farm settled down at Dumbiedykes, and, without as much as saying, "By your leave," took possession of that now famous hole in the burr oak tree, where so many birds and the fated flying-squirrels had preceded them. A brood of golden woodpeckers had hatched and gone. Of that I was sincerely glad. They were a noisy generation, and the chattering of the youngsters while the mother sought to still their throats and stuff their stomachs at last got somewhat on our nerves.

The bees, however, are ideal neighbors. I always did get on well with bees. My father was an enthusiastic beeman when I was a lad at home, and 
at the risk of raising questions as to my dear old mother's reputation for veracity I will here put on record the quite unbelievable statement which I have often heard her make: that as a tiny urchin I had one certain summer day seated myself in front of the hives, where the bees had gathered thickly on the outside of their box to escape the heat, and played with handfuls of them without being stung. I have been since, however, not always by honey bees.

And so we really gave the wild bees welcome as they entered in the oak, and throughout the long midsummer days and well into the autumn the busy droning of these thrifty little workmen added a new element of charm to our surroundings. And as they gathered from the fields and flowers their winter store of sweets, their hapless brethren of the idle class grasshoppers, crickets and the rest - were squandering the shining hours 


\section{The Road to Dumbiedykes}

with not a thought of coming trouble in their tiny brains.

Most people despise spiders. I do not know whether they are more brilliant in achievement than the ant or not, but their handiwork is surely more spectacular. There is a beautiful big, black velvet fellow, for instance, with yellow plush trimmings, that spreads a net upon the barberry every summer that is certainly a geometric gem. They say he is poisonous. Well, I have no doubt he has been endowed, like the rest of us, by Nature with some means of providing himself with food. The manner of his operation is not his fault, any more than is that of the robin going into the earth with a well-sharpened beak for his legitimate prize of war.

The month of August finds the insect tide at its very height, and when about the evening of the fifteenth day arrives we listen for the first fiddling of a katydid. You will always hear 
Toilers and Idlers of the Shining Hours

them before you see them. Many who have heard them always have never yet seen one. They are quietly feeding or sleeping during the daylight hours, and their pale green garment conceals them perfectly as they lounge or lunch upon the foliage. The first night there is commonly but one Katy with leg-development sufficient to enable her to begin operations. The second evening there will be an answering call, and about the third night the trees and shrubbery will be vibrant with the music of these curious harbingers of fall. It is now "six weeks to frost," so the old saying goes.

A colony of wasps were unwise enough to build one summer in a fold of an awning that had not been down for weeks, and when the rope was finally slacked and the poor creatures precipitated nest and all to the ground below, there was tall hustling on the part of the innocent wrecker of their home. They were simply inconsol- 
able, and literally hung around the place of their discomfiture for days, evidently in the hope that in some way unknown to waspish intellects their fragile ruined domicile might be restored; this, too, in the face of every effort to dislodge them with the garden hose and other discouragements. They were finally dispersed, however, by a resort to the fumes of gasoline; so the Germans were not the first to introduce a modern form of warfare.

I love the lazy, awkward bumble bee. He is not so nervous and peppery as his smaller brother in the same line of business. He nests in the ground - hence his name "humble," I suppose. He "bumbles" around so deliberately, pays so little regard to other people, attends so well to his own affairs, and puts up such a superior brand of honey, that he is altogether one of the desirable citizens of the entomological world. He does not 
lay up his stock in such shape as to tempt the cupidity of men, but farm boys know that the bag of honey he carries home is the very essence of the choicest flowers. We used to catch and kill them just to rob them of the hard-earned fruits of their innocent labors. Why do boys have the killing lust so highly developed, anyhow?

Down in Congress the other day, in the course of a rather rancorous debate, one member, an old hand at the business, said that his opponent a new member of the House-reminded him of a "bumble bee" that is "always biggest when first hatched." I do not know whether that old guardsman was up on the natural history of the bee or not. I have not cared to fumble with their nests myself, so I can neither affirm nor deny this statement in reference to the early life of baby bumble.

Everybody loves a cricket. I cannot say much for his gait, or that of 
his friend the grasshopper. You never know just what the next move is going to be. I certainly do not envy these ephemeral creatures their mode of locomotion. To be compelled to wind yourself up, spring the traps that unloose your various legs, find yourself projected aimlessly somewhere into space, and fall all over yourself in the landing may seem to them a pleasant enough way of going through life, but the movement seems to need what a dancing teacher might call "smoothing out."

There is something most pathetic about the last days of the cricket. In some way the grasshoppers and the katydids take their leave so quietly and so privately that you know little or nothing of their final exits. But the cheery chirping cricket does not make so graceful a goodbye. The first frosts dull the edge of his music, and give him rheumatism. $\mathrm{He}$ becomes a wandering wreck along the 
Toilers and Idlers of the Shining Hours

sidewalks or in the grass alongside, and his last effort at being cheerful is such a pitiful little squeak that you want to take him in by the fire and thaw him out, especially since he has been such a welcome visitor around the hearth when in better form.

And, alas! These are not the only fragile folk in this heartless old world of ours to lose friends and admirers after looks and voice have gone.

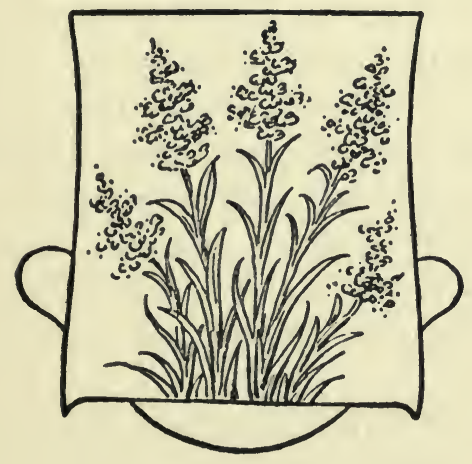





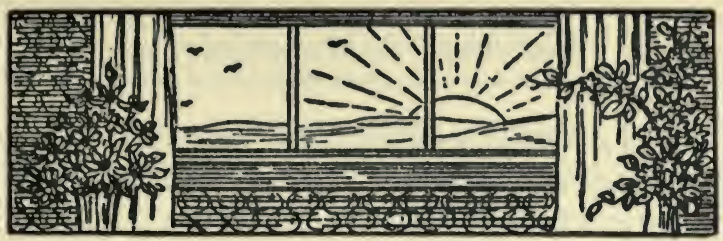

\section{CHAPTER XI \\ The Rain Upon the Roof}

It was now late in August. For weeks there had been practically no relief from the burning drouth. Day after day the sun had set in copper only to rise again in brass. The bluegrass looked as if dead beyond recall. The leaves were turning brown, and falling rapidly. Now and then cloud-banks would appear in the distance, and an occasional flash and distant thunderpeal seemed to signal the beginning of the end, but the promise would fail to be fulfilled, and the suffering was all the greater because of the hope that died.

At length, however, when the thirsty earth was in despair, one evening there was scattered all along the west- 


\section{The Road to Dumbiedykes}

ern horizon a gorgeous panorama of sea and shore and sky and distant mountain heights, with great promontories projecting into misty gulfs. In the offing mystic purple islands floated in a golden ocean. For a time it seemed impossible to distinguish the line of demarcation between the mainland of the earth and the vapory shadows stretching out and up through apparently immeasurable seaward distances. And that night came the change: first the fiery vanguard of a heavy storm; then the settling of a steady all-day, all-night rain-the kind that makes this great globe of ours inhabitable. Have you ever known the comfort of watching or listening throughout long hours to this blessed streaming of the skies upon parched fields, dust-laden foliage and shingle roofs? If not, then we have found another thing denied to you poor city folk.

On those rare days when a long, late-summer drouth is at last being 


\section{The Rain Upon the Roof}

thus effectually broken, if you are a boy, old or young, and living on a farm, you may get a lot of satisfaction out of contemplation of the great miracle being wrought if you will seek with the live stock the shelter of the barn. In there somehow you seem to be closer to the heart of the things most vitally affected. You know that all animal and vegetable life has been suffering tortures from the intolerable heat. Birds and beasts, fields and forests alike have felt the strain far more than we humans with our various artificial devices for ameliorating our own situation during such a period. But what of those galled and sweating teams, those thriftless cattle in bare pastures seeking the shelter of some friendly tree, and fighting the tormenting flies that permit no peace by day or night? What of the poultry with uplifted wings almost too tired and hot in their feather coats to forage for their slackening food? What of that once-fine 


\section{The Road to Dumbiedykes}

field of corn that gave such promise at the last full moon - now "fired" and on the brink of ruin? What of the curling leaves on elm and maple?

I have indeed vivid recollections of a hayloft in an old red barn from the door of which we used to watch this great event of the final coming of the heavy rain, and I can hear still the comforting monotony of that steady patter on the roof bringing life and hope renewed into a languishing world. You farm-bred fold know full well, as you watch the slow discharging of the thick gray clouds, the astounding transformation now at hand.

At Dumbiedykes, alas, there is now no barn - only a garage. And who could stand or sit for hours in an automobile stable and welcome with grateful heart a two-days rain? Nobody, of course. There are no friendly eyes or ears or muzzles in the stalls to keep you company. There is no hay overhead. No feed-bins, straw or meal- 


\section{The Rain Upon the Roof}

tubs. Just your trusty motor, and when it is not going it speaks to you not at all. True, purring down the long road it has a voice of which you may get very fond. Besides it minds not drouths, nor heat, nor cold, if you are as good to it as to your horse. And yet a garage can never be a sureenough old barn, filled with the tenants and the products of the fields.

Once we kept ponies where the big machine now stands, but they, like their little mistress, have gone now far away. A Shetland of uncommon quality and wisdom was the one particular pet in those days; in fact a frequent caller inside the cottage proper, until once upon a time he got his pudgy stomach wedged in between two closet walls, whereupon we had something of a time extricating him from a real predicament.

The cottage porch is well protected from both wind and rain. Here therefore let us sit and watch the dry earth 


\section{The Road to Dumbiedykes}

drink, and listen to the gurgling of the water in the spouts, or the dripping from the eaves. And if it grows too damp at last, there always waits inside a certain friend - the back-log. And when the day is done, and the scorched earth is still demanding more, yet more, there is still the comfort of that pillow as the rain pours on unceasingly through the blackness of the night! You are so snug and dry and satisfied. The wind is rising now. It shakes a cataract upon the roof from off the overhanging branches, and while you are on your way to dreamland its deep retreating roar through the weeping, bending oaks seems an echo of a heavy surf upon a stormbeat shore.

And the fresh beauty of a world renewed that greets the morning sun! Who shall paint it? 


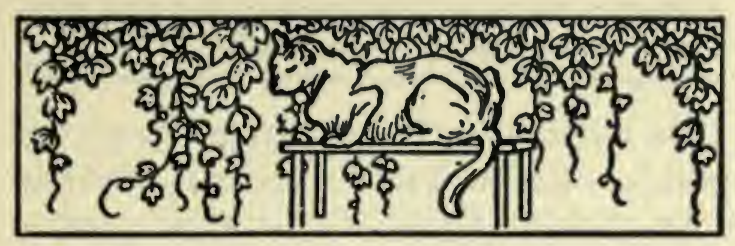

\section{CHAPTER XII}

\section{Fireside Fancies}

With the first advance of the autumn we begin to lay the open fire. In fact, so fond we are of the blazing logs upon the big brick hearth that we take advantage of the slightest drop of the mercury in the thermometer all season through to gather round the chimneybreast, and set the flames a-dancing; and if the day be wet as well as cool outside we have little trouble in making ourselves believe that after all life is not altogether dependent upon perpetual sunshine, even though clear skies and balmy airs are usually deemed essential to the enjoyment of the country.

It is astonishing how few there are in these degenerate days who know 


\section{The Road to Dumbiedykes}

how to lay the foundations for a successful fire. Your modern servant knows nothing whatever about backlogs and their proper placing. The wood is just thrown in regardless quite of relative sizes and positions, and the kindling as apt as not will be on top. The prime object of the open fire is good cheer and stimulation. Improperly begun is never rightly finished. The fire hesitates, struggles, never really gets a-going, and soon its obvious discouragement reflects depression in the room. The open fire must be free and active. Of course there is nothing like good, sound, dry hickory or driftwood to give it zest, but these are growing as scarce these days as terrapin, and often time we find ourselves trying to make believe we are satisfied with some half-decayed old stuff, jollied along at frequent intervals with pine slabs or the débris of crates and boxes from divers sources. However, any kind of glow is better than no fire when [130]. 


\section{Fireside Fancies}

the world is hung with black without, and winds are high and searching.

Byron says "'tis sweet to hear the watch dog's honest bark bay deepmouthed welcome as we draw near home," but if the day be cold and the frosty air is nipping keenly at your ears and finger tips, show me the blue smoke rising freely from the chimney top. I know what waits within, and when the dressing-gown and slippers and the rocker are in place the world may hang; I care not. For are not my old friends there upon the shelves, the old gray cat with folded paws asleep there by the fire, and Billy knitting?

For me old friends, old books, old vintages, if I may. And yet an old friend may be found among people you have but recently discovered. Real friends are born, not made, and when you meet you know without very much ado that you were intended for friends from the very beginning. You have had similar thoughts, similar

$$
\text { [ I3I ] }
$$


tastes, similar aspirations, since you were both started on your journey, and the joys of a congenial companionship that only needed contact for fruition are not long in springing into flower. It is as if you had always walked together. The only trouble is that in a lifetime you do not meet many of those with whom close friendship would be possible. There is such a labyrinth of highways and byways to be traversed that it seems commonly an accident if a real friend happens actually to cross over into your own lifeline and closely parallels your course. Fortunate indeed are those thus thrown together by the fates charged with the handling of our great affairs.

There is of course a great difference in people in respect to this matter. Some are quite satisfied with the froth of commonplace acquaintanceship. If the veneer of the merely conventional happens to match their own they may live content in a world that seems to [132] 
their shallow natures filled with most congenial people; but those in whom the currents that touch the nobler things of life run deep and high have not often the great good fortune to join themselves in spirit with more than one or two real friends. We all know plenty of people, but how many come into our lives with whom a perfect mutual understanding is possible? The rarity of such companionships in actual life explains and emphasizes the priceless value of the literature of the ages. Here at least we may turn and be sure of finding thoughts and sentiments that confirm our own experiences, or give expression to our own ideals.

I pity the man or woman who is only happy and content where the band is playing. Possibly this is sympathy quite wasted. Possibly those who find all they require in life at the "movies" or in the whirl of the town have the rational view, but there are some who do not court constant touch with the 
passing rush and roar. There are some who have certain resources within themselves. There are people who could spend a blustery week by an open fire with only a good book or a friend - I use the word in its highest interpretation - and not be miserable. I have known folk who, if need be, would find no hardship whatsoever in passing a winter alone in Terra del Fuego - that is, if before being thus marooned they might be provided, say with Shakespeare and Marcus Aurelius. If I were to be thus isolated, however, for any reason from so-called civilization, I should wish to extend the list to take in first of all the Scriptures. I must say I do not know which fascinates me most, the flowery imagery of the Prophets or the moral beauty of the Sermon on the Mount. Then, again - queer conceit, isn't it? - I think I should ask also for my old Montaigne, and if there were room in the boat that was to set 
me ashore I should surely ask for Thoreau's Walden, and copies of Virgil, Horace, Wordsworth, "Bobby" Burns, and our own author of Evangeline and Hiawatha. Yes, and I would not forget a precious wellthumbed Shelley, in which is written this inscription - "With happy Christmas greetings from a friend." The hand that wrote that line in the long ago could not direct the pen with such copper-plate exactness now, I fancy, but the skylark ode is there, the immortal "Hymn to Pan," and the "Song of the Faded Violet."

How fierce and all-consuming are those first newly-kindled flames upon the hearth! Their primal inspiration may be nothing more substantial or enduring than pine and paper and a tiny match, but how they leap and blaze and set the flickering shadows dancing! In all this world there is nothing so joyously contagious. All the world loves to watch the merry 


\section{The Road to Dumbiedykes}

playing of these first pure spirits of the fire, and as they gradually become quiescent spectral pictures pass.

A schoolboy with his freshman German. The lesson Schiller's impressive poem, "Das Lied von der Glocke" - the old church bell's story of human life from the christening to the grave, as seen through centuries from the belfry tower. A boy is called upon to read and translate. His lines conclude:

O! Dass sie ewig grünen bliebe, Die schöne Zeit der jungen Liebe!

And as the boy finishes and takes his seat the old professor seems to dream. The boy had said: "A free translation of these lines might be

Would that it might abide forever

The beauteous springtime of young love.

"Yes, that may do," says the old instructor somewhat wearily, "but really there is no such thing as render- 
ing completely in English the full beauty of the original." $\mathrm{He}$ then gave the literal interpretation of the lines, and in his voice more than one of the boys detected a trace of emotion which they would not have guessed had place in the old man's breast.

Within twelve months after this little incident one student had deserted the college halls forever at the call of something in the eyes of a maiden fair. She sits there now with him, after the lapse of I should not just care to say how many years, by the open fire, and together they contemplate the slow combustion of the logs. A great calm has settled down upon the hearth since the pine and paper first rushed aloft in smoke. The imprisoned sunshine of summer days long gone now finds a glad release as the friendly fire burns on in steady moderation. The "sap" is seeping too from out the ends of that heart of oak as the heat expands its fibres, and an echo of the beating of the 


\section{The Road to Dumbiedykes}

early and the later rains is heard far in the distant forest depths.

They say that only mountaineers transplanted from their accustomed heights to wear out their lives upon the dead levels of the plain ever really die of Heimweh. I am sitting later than is customary before the smouldering embers. The clock is on the stroke of twelve. The glowing coals are turning fast to ashes. Where in the beginning there was life and light and jollity, now all grows cold and gray and cheerless. Happily, however, the sweet oblivion of sleep impends, and soon the morning light will break.

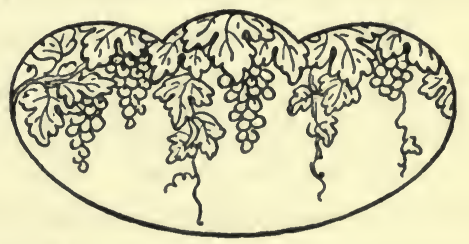




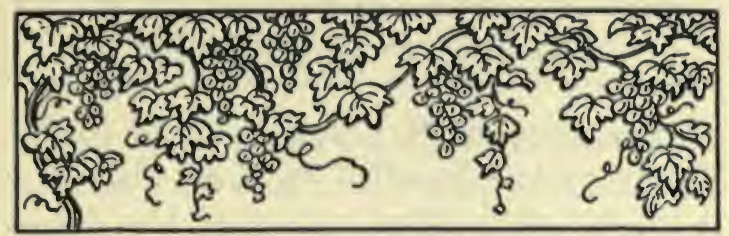

\section{CHAPTER XIII}

\section{The Beginnings of Tomorrow}

One born and reared within the tropics, who had spent several years in the North Atlantic states and Canada, once said to me, "The two most beautiful sights in all this world are the New England and St. Lawrence River forests after the frost has blended with the vivid greens the brilliant yellows, browns and scarlets of the maples; and - a snowstorm!"

It is not difficult to understand this viewpoint. The eternal sameness of the southern atmosphere and landscape must become monotonous. The gorgeous October coloring of our eastern hills and the wild exhilaration of the snowflakes riding on the winter wind must strike one unfamiliar with 
such scenes with all-compelling force. So let us be thankful that we live in a latitude where Nature resets her stage so frequently that we do not tire of one great act before another is upon us.

As winter drags on to its close the lure of the vernal sun is well-nigh irresistible. Most of those who are compelled to pass their days in the man-built town are then moved by some instinct latent in every human breast to seek the God-built temples of the out-of-doors, but as the springtime leads us forward into golden summer days and deep-fruited autumn follows on to crown the harvest of the year, the killing frosts cut down the transient beauties of the fields and drive us back again upon ourselves. And yet I never quite subscribe to the poetic proposition that now

The melancholy days have come

The saddest of the year.

What is there "melancholy" about complete fulfillment of a promise? 


\section{The Beginnings of Tomorrow}

What "sad" about the attainment of a heart's desire? The bud blossoms, spreads its petals, bears the precious seed that insures its own sweet perpetuity, and goes its way without regret. The leaves at last drop willingly to their rest. There is no struggle. All things are working towards a destiny that from the beginning has been clearly manifest. We may well weep over life cut down before its time. We may break our hearts over things that might have been had certain planetary bodies come in conjunction at the proper time. But the normal closing of careers that have wrought that which has from the beginning been assigned should bring not sorrow but real satisfaction. The devastation of a waving wheatfield ere the grain has filled affords just cause for lamentation. Not so the yellow garniture of the heavy-laden sheaves; for Boaz has his rich reward, and Ruths may glean as the reapers pass. 


\section{The Road to Dumbiedykes}

The ancients celebrated the "harvest home," even as we should still. From time "whereof the memory of man runneth not to the contrary" the ripening of the grapes of industry has been made the occasion of feasting and rejoicing. The "Good-bye to Summer" is not necessarily a song of sadness. Rather should it be hailed as a true hymn of triumph. In the apparent end is the eternal promise of the future.

During our last few weeks in the open the air takes on a peculiarly exhilarating quality. The stars sparkle brighter overhead. Through dreamy days the blue haze hangs steadily on the horizon. The gregarious wild canaries stop with us over-night on their long flight towards the sunny south; and out of the darkness overhead there comes that truest of all calls of the primeval world - the "honk-honk" of wild geese flying swiftly through the night on wings unwearied. 


\section{The Beginnings of Tomorrow}

And so we gather the ripened seeds and clear the ground of the frosted flower-stalks in the garden, and prepare the rose vines against the advent of midwinter days. We know that the trees and shrubbery have already formed the nucleus of the new year's foliage; and we turn away with thankful hearts in certain knowledge of the beauty that will rise again.

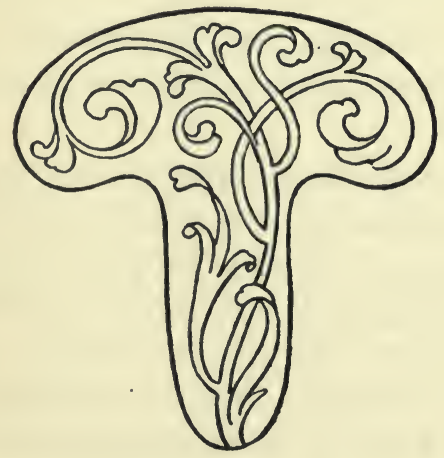





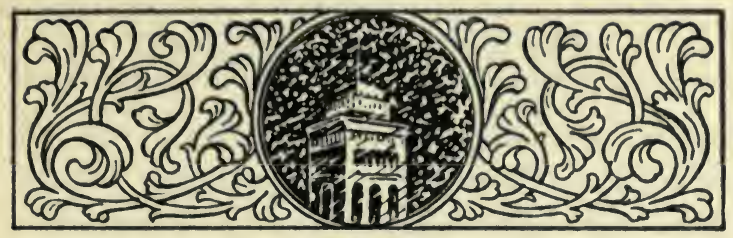

\section{CHAPTER XIV}

Back to the Bright Lights

Around the Auditorium's grim, gray tower one bleak December night the lake winds howled and whirling snowflakes drifted. City and country alike were in the embrace of the first blizzard of the season. Up and down the busy boulevard the myriad lights of taxicabs and limousines were gleaming.

Farrar's Carmen may be all right, but most of those who rolled Loop-wards on the night of which we speak preferred her Madame Butterfly; and all were happy when the storm-bound city streets outside had been exchanged for the atmosphere of spring and cherry blossoms with which the stage-setting for this opera is invested.

$$
\text { [ } 145 \text { ] }
$$




\section{The Road to Dumbiedykes}

The tragedy moved forward to its climax. Personally, I have never thanked the author of this libretto for saddling upon an officer of the United States Navy the opprobrium that naturally falls to Lieutenant Pinkerton in the play. Moreover, the character of Butterfly herself is no more Japanese than Pinkerton is typically American. Both would fit more logically into Latin rather than northern environments. Besides, the psychology of the situation presented is inimical to the cultivation of that spirit of mutual respect and consideration which is so greatly to be desired at this time between the nations. The desertion of the trusting female Nipponese by a man wearing Uncle Sam's uniform, even although the fanciful creation of the imagination, when publicly paraded in grand opera, is not calculated to stir the pride of any American, nor stimulate the halting friendship of our trans-Pacific neighbors. However, this 


\section{Back to the Bright Lights}

is not to be an essay on a topic purely speculative nor a study in comparative ethnology. We can at least enjoy Puccini's art and Farrar's, and forget international relationships in the presence of the working of elemental passions.

Under the magic spell of Campanini's wand, great waves of harmony break and roll and die away in the remotest reaches of the farthest galleries; and as the last echoes of a real orchestral triumph are lost somewhere amidst the heights and depths of the lofty walls, I am carried back in spirit to a day in the distant past. You who have never heard the angels singing among the majestic arches of old York Minster, as the thousand-tongued organ floods that vast cathedral's rich interior, have something yet to live for. And if you cannot thus indulge yourself, at least buy William Winter's little book of gems, "Gray Days and Gold," and enjoy a poet's inspiration. 


\section{The Road to Dumbiedykes}

The power of great music over an imaginative soul is absolute.

And now poor Butterfly is standing at the window in her all-night vigil. The lights have been turned off throughout the body of the theatre. Only the soft glow reflected from the stage outlines the brilliant audience. The violins sing sweetly their plaintive messages.

If you would enjoy grand opera to its utmost, centre not your mind too much upon the puppets up in front. Concentrate not at all upon the vocalization, however perfect. With all your faculties alert listen intently rather to the story being told by strings and reeds and brass. All else is secondary. When I am blind then take me still to opera.

Two thousand human hearts are being played upon, even as the artiste there in front is sweeping with delicate touch the responsive chords of that golden harp. A perfume of roses is wafted from the boxes. There is gline 


\section{Back to the Bright Lights}

of jewels flashing in the semi-darkness. You have touch of elbow, mayhap, as you sit in hushed expectancy, with those who are near and dear. You feel the exaltation of the hour. Forgotten is the daily grind. Forgotten the frozen cabbies of the curb outside, and the motor fleet in waiting in the snowy midnight. ' You are soothed or saddened, depressed, uplifted, satisfied or comforted and your imagination stirred just according as your mood, your individual capacity, or attending circumstances may admit.

An hour later in the warmth and comfort of the library, I viewed many things in retrospect. Happy as I had surely been under the witchery of those high appeals to the finer sensibilities, my mind kept ever turning back from a contemplation of the cherry blooms with which poor Cho Cho San had decked her little home in honor of the coming of her lover to a cottage in the wood where the romance 


\section{The Road to Dumbiedykes}

of real life has a setting on a truly sylvan stage, where the passing of the years has left some vacant places 'round the fireside, where peace and happiness and sweet content have had a real existence.

I often wish I were not compelled to migrate each October from that little nest among the trees. I often wish I might remain through snow-bound winter days and nights, and so keep always close to Nature's heart. But my life has not been so ordered by the fates. I say farewell to Dumbiedykes each autumn only because a call that comes from a certain office desk is not to be ignored if I am still to pursue appointed tasks. And so when North winds whirl the dead leaves down the road we must prepare to go. Fortunately this is a compensating world. He who seeks may find. Even in the bright lights of a great city's manifold activities there are fruits and flowers worth while. Nights that are "filled 


\section{Back to the Bright Lights}

with music" may usually be relied upon to dissipate the "cares that infest the day." I certainly do love the roses and the orchids and the song-birds of the opera. But after all the coin is counterfeit. And so at last I come back always to the picture of a certain peaceful spot where bright old-fashioned flowers are waving in the summer air, where hollyhocks do rear their decorative heads, where the delicate fragrance of the four-o'clock is spread upon the night breeze as the sun goes down, where a catbird perches on a honeylocust bough and twitters through his cheery repertoire as his mate sits on the nest beneath him in the hedge.

I confess the alluring charm of Oriental pearls about my lady's neck, and of diamonds glittering gaily in the bright lights; but on an early morn in June there are a million jewels in the bluegrass that put all your gems of "purest ray serene" to shame; and when at dusk the glowing Venus holds 


\section{The Road to Dumbiedykes}

her evening court, the highest art of Tiffany pales quickly into insigniticance. And as for Mary Garden - well, there is one thing sure: no note, however highly-paid or pitched that ever floated o'er the footlights of any stage in all this world can bear comparison with those that ripple from the bursting throat of a joy-mad bobolink or match the sweetest sound this earth affords - the distant call of a meadow lark across green fields.

And yet there is one note - though it is not given to everyone to hear it - transcending even these: the note your heart finds in the voice of one you love.

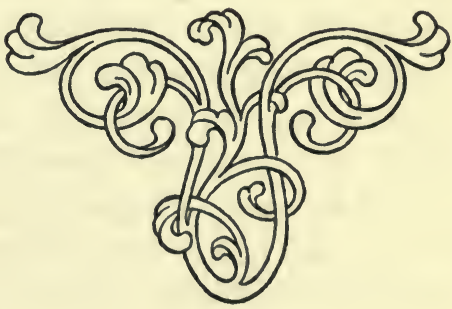


PRINTED BY R. R. DONNELLEY AND SONS COMPANY AT THE IAKESIDE PRESS, CHICAGO, ILL. 



\section{.}$$
\text { - }
$$ 

THIS BOOK IS DUE ON THE LAST DATE STAMPED BELOW

\section{AN INITIAL FINE OF 25 CENTS} WILL BE ASSESSED FOR FAILURE TO RETURN THIS BOOK ON THE DATE DUE. THE PENALTY WILL INCREASE TO 50 CENTS ON THE FOURTH DAY AND TO \$1.00 ON THE SEVENTH DAY OVERDUE.

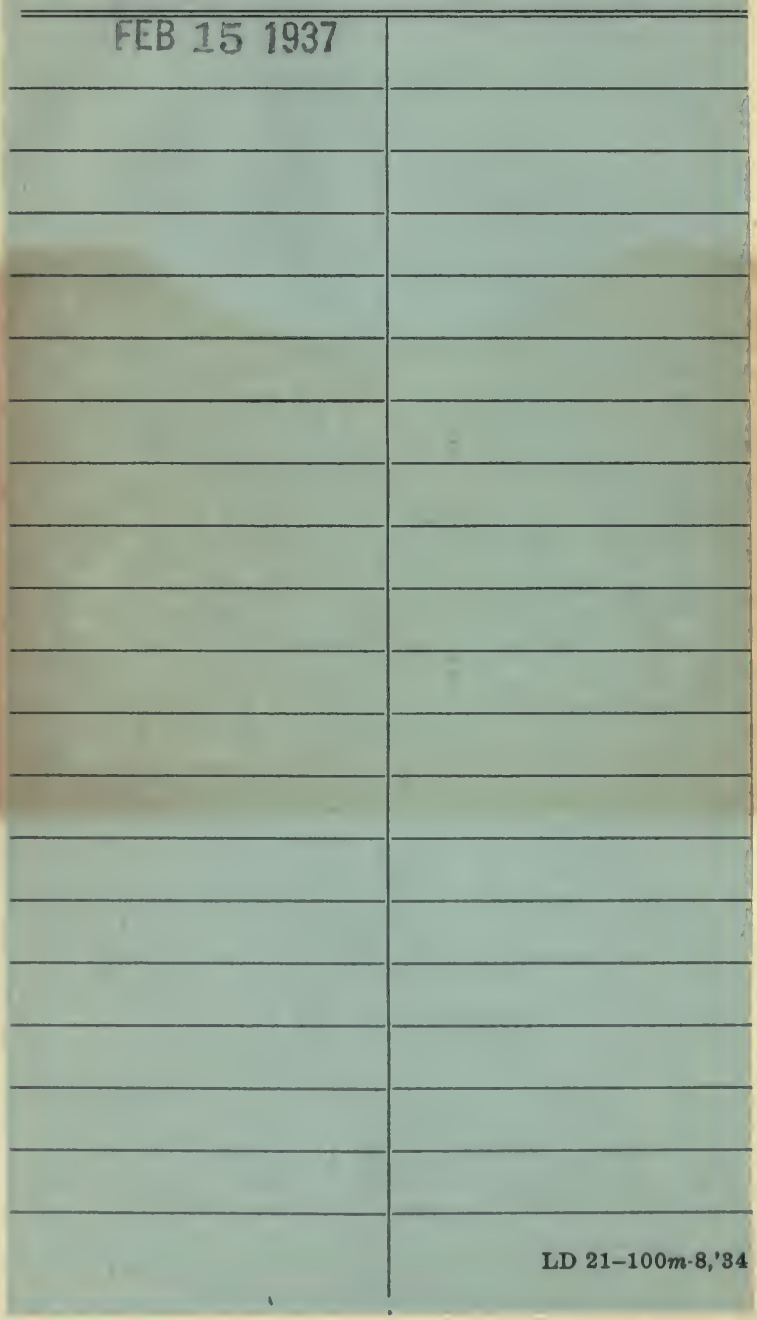


dykes 


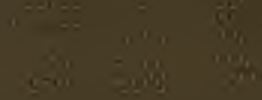

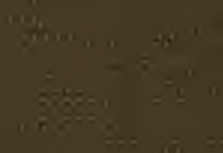
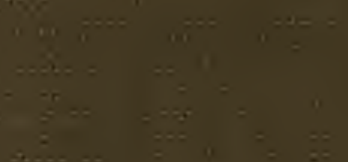